\title{
Social Media and Articulation of Radical Narratives in Afghanistan
}

A Research and Policy Paper

Niamatullah Ibrahimi I Musab Omer | Mohammad Irfani

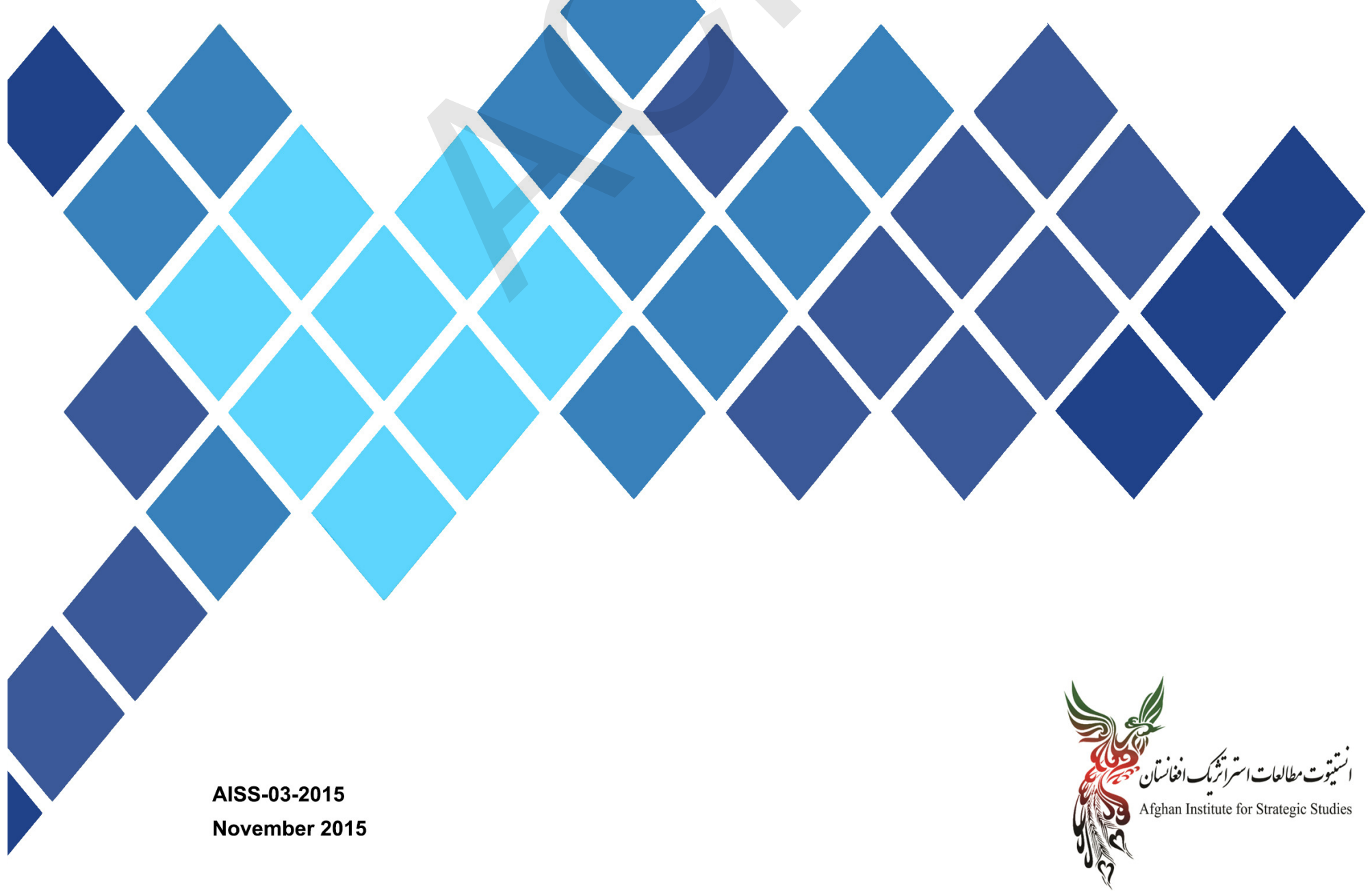


This Page Intentionally Left Blank

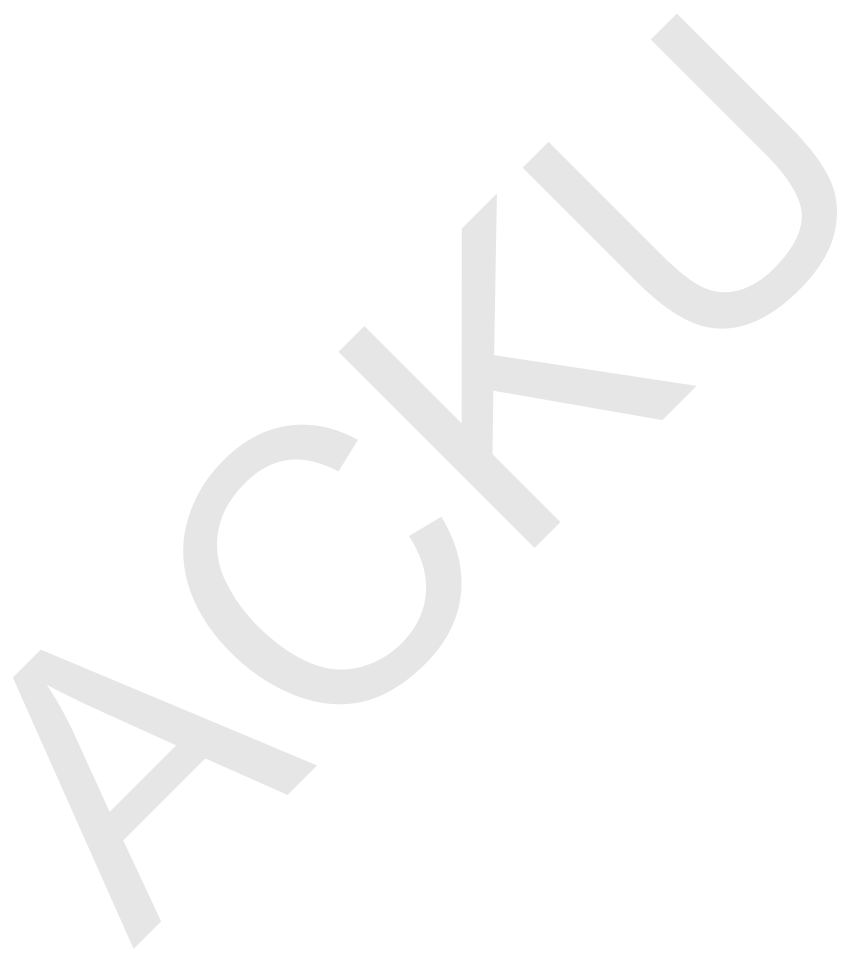




\section{Social Media and Articulation of Radical Narratives in Afghanistan}

Authors: Mr. Niamatullah Ibrahimi, Mr. Musab Omer and Mr. Mohammad Irfani

Project Coordinator: Mr. Musab Omer

Research Design and Report Peer Review

- Dr. Sarah Logan, Research Fellow, State, Society and Governance in Melanesia Program, Australian National University, Canberra, Australia

- Prof. Shahram Akbarzadeh, Research Professor, Faculty of Arts and Education, Alfred Deakin Institute, Deakin University Australia, Melbourne, Australia

Field Researchers

- Mr. Khalid Yousafzai

- Mr. Fazel Obaid

- Mr. Basir Moheb

- Mr. Bashir Ahmad Osmani 
This Page Intentionally Left Blank

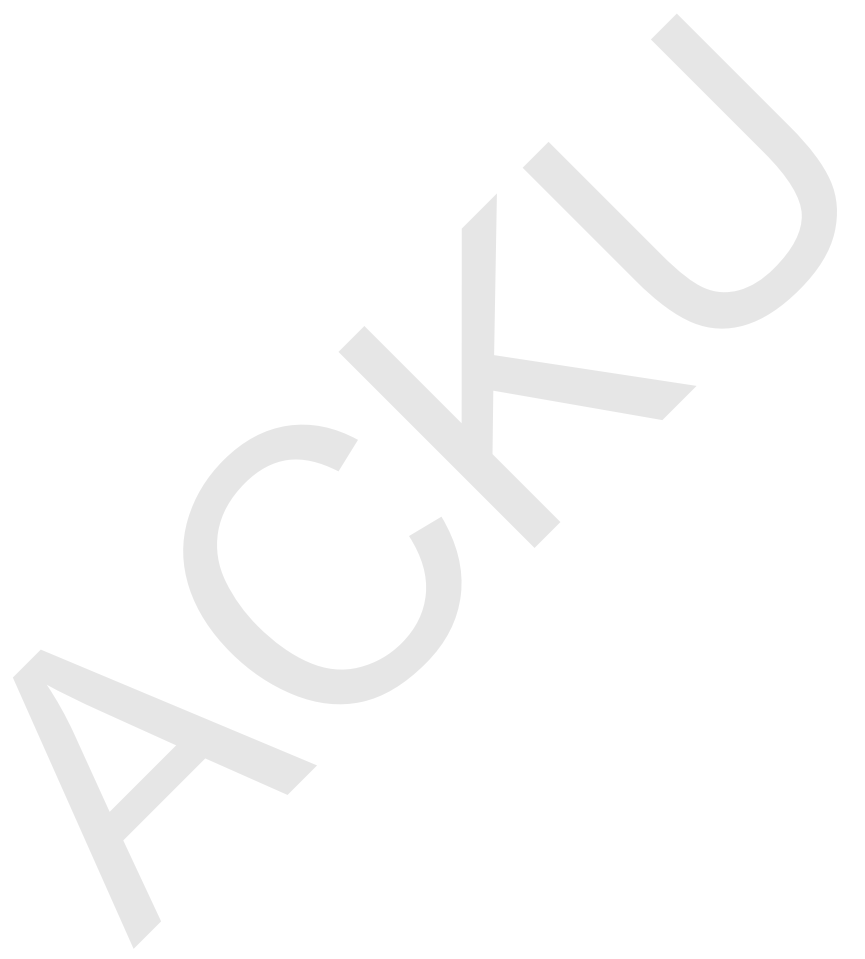




\section{CONTENTS}

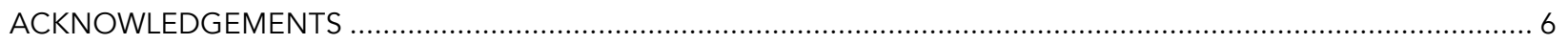

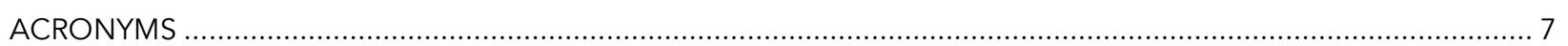

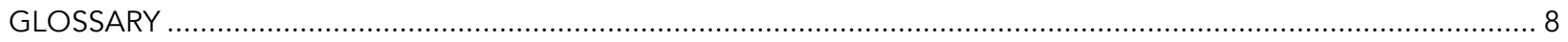

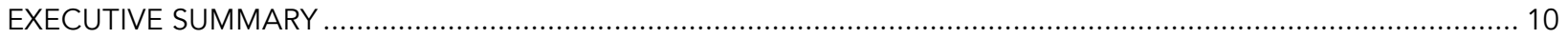

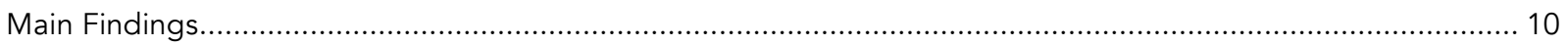

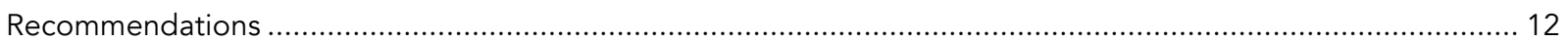

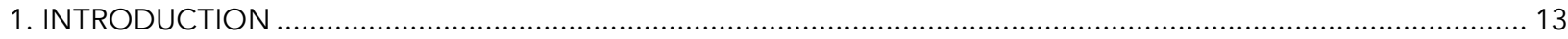

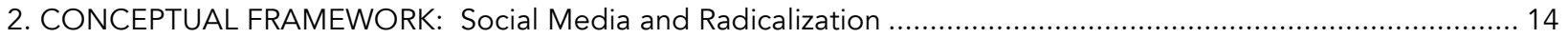

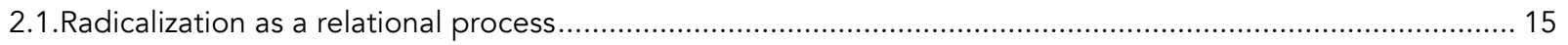

2.2.Social media as an instantaneous, interactive and personalized means of communication ............................. 19

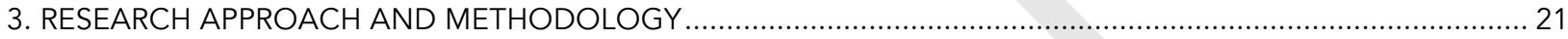

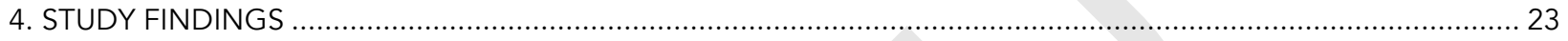

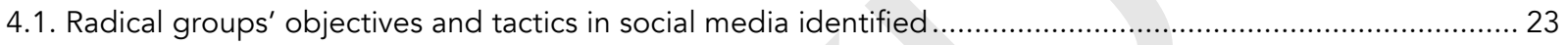

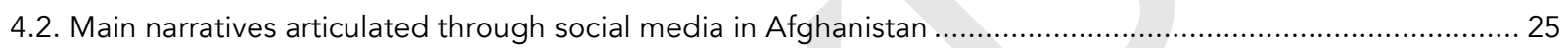

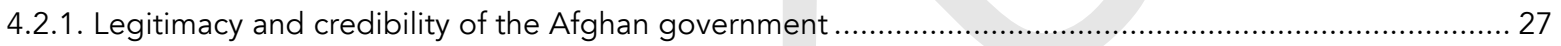

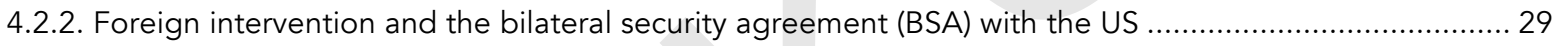

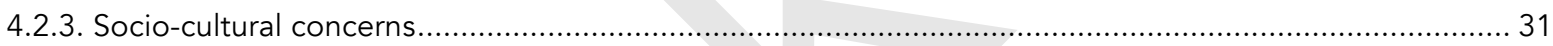

4.2.4. Strategies for social and political action and views on jihad and mujahideen ...................................... 35

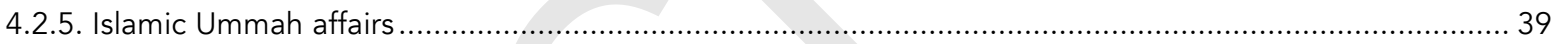

4.3. The role of Taliban hymns and songs in the radicalization processes in Afghanistan .................................. 41

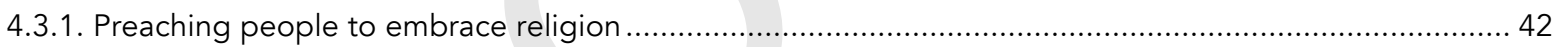

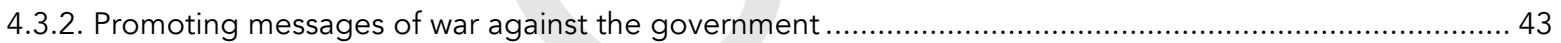

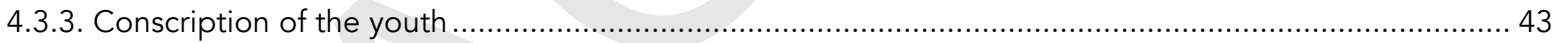

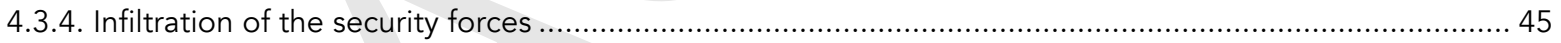

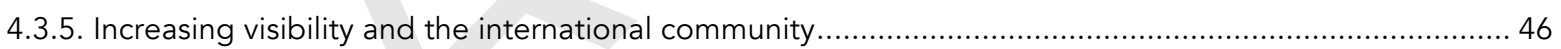

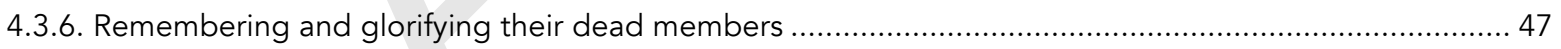

4.4. People's perceptions about the radical narratives in social media .......................................................... 48

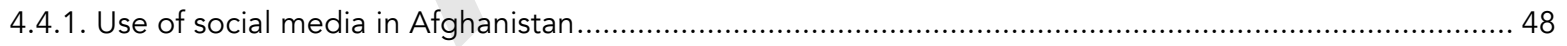

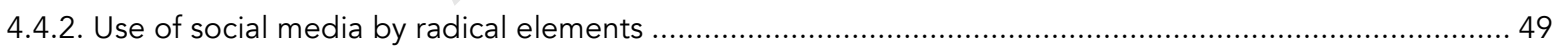

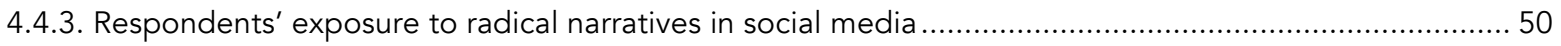

4.4.4. Public and civil society response to radical messages in social media................................................. 52

4.4.5. Government response to radical narratives and counter radicalization approach .................................. 56

4.4.6. Respondents' views about government policies for counter radicalization .......................................... 58

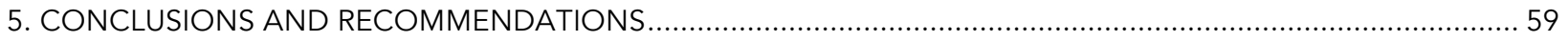

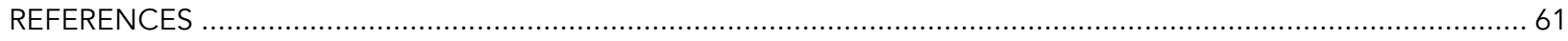

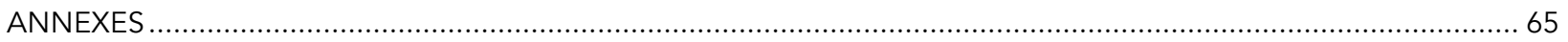

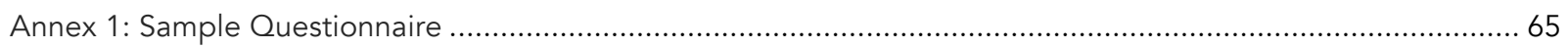

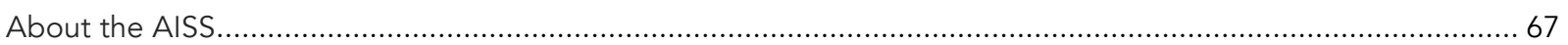

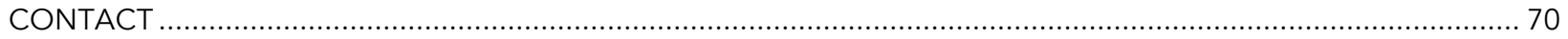




\section{ACKNOWLEDGEMENTS}

The authors are extremely grateful to the Afghan Institute for Strategic Studies (AISS), for its logistical support, and United States Institute for Peace (USIP) for its generous financial contribution to this project.

We are grateful to our peer reviewers, Prof. Shahram Akbarzadeh and Dr. Sarah Logan for their thoughtful and expert comments and insightful feedback during the preparation of this paper. We would also like to thank Professor Shahrbanou Tadjbhaksh and Mr. Abdul Ahad Mohammadi for their advice in the conceptual phase of this research, and Mr. Bilal Sarwary for conducting research on the Taliban hymns in Afghanistan.

We deeply appreciate Khalid Yousafzai, Basir Moheb, Fazel Obaid and Bashir Ahmad Osmani, for their time, diligence and for showing genuine interest in carrying out field research. We would also like to record our gratitude to Zubair Nazeer for copy editing the final draft of the paper.

Musab Omer November 2015, Kabul 


\section{ACRONYMS}

AISS Afghan Institute for Strategic Studies

ANSF Afghan National Security Forces

BSA Bilateral Security Agreement

GoA Government of Afghanistan

HIA Hezb-e Islami Afghanistan

ICT Information and Communication Technology

ISAF International Security Assistance Force

ISIS Islamic State of Iraq and Syria

MCIT Ministry of Communication and Information Technology

MolC Ministry of Information and Culture

MoD Ministry of Defense

Mol Ministry of Interior

NATO North Atlantic Treaty Organization

NDS National Directorate of Security

NUG National Unity Government

SCO Shanghai Cooperation Organization

USIP United States Institute of Peace 


\section{GLOSSARY}

Aalim - plural Ulama, a learned scholar of Islam in any of the Islamic sciences, such as: Quran commentary, Hadith, philosophy, etc.

Ahl-e-Sunnah - derived from the Arabic word Sunnah, referring to the sayings and actions of the Prophet Muhammad as recorded in the Hadith; those that follow the way of life led by Prophet Muhammad are called Ahl-e-Sunnah.

Bay'ah - in Islamic terminology is an oath of allegiance to a leader.

Burqa/Chadari - an enveloping outer garment worn by women in some Islamic traditions to cover their bodies when in public.

Da'wah - the purpose of da'wah in Islamic theology is to invite people, both Muslims and non-Muslims, to understand the message of Allah as expressed in the Quran, the teachings of Prophet Muhammad, and to inform them about Islam.

Figh - the theory or philosophy of Islamic law, based on the teachings of the Quran and the traditions of the Prophet.

Hadith - a collection of traditions containing sayings of the prophet Muhammad along with accounts of his daily practice (the Sunnah) that constitutes the major source of guidance for Muslims apart from the Quran.

Hijab - a veil worn by Muslim women to cover the head. It is representative of modesty, privacy, and morality.

Hizb-e Islami - an Islamist organization that was commonly known for fighting the communist Government of Afghanistan and their close ally, the Soviet Union

Imam - a person entrusted with an Islamic leadership role to both lead prayers in a mosque as well as to participate as a community leader or to give guidance to community leaders.

Islamic Emirate - the state established in 1996 by the Taliban when they began to rule Afghanistan and it ended with their fall from power in 2001

Jamiat-e Eslah - An umbrella organization registered with the Ministry of Justice in Kabul, focusing on social, cultural and educational activities.

Jihad - with a literal translation of 'struggle', it is most closely associated with 'holy war'. Regardless, the term speaks to a believer's internal struggle with faith, or with the struggle to maintain and defend Muslim society and Islam externally.

Kuffar -plural of Kafir, an Arabic term used in an Islamic doctrinal sense for unbelievers or infidels, as well as a deeply derogatory term employed by proponents of conservative Islamists against non-Muslims. 
Madrassa - derived from Arabic, is the term for educational institutions. However, more contemporary usage associates the term with Islamic religious schools.

Mufti - a Muslim legal expert who is empowered to give rulings on religious matters.

Mujahiddeen - plural of Mujahid, the term is generally used for the people engaged in jihad.

Mullah - derived from an Arabic term 'Mawla' meaning master or guardian. In large parts of the Muslim world the term is commonly referred to local Islamic clerks or mosque leaders.

Nowruz - the first day of spring or the Persian new year, when people from diverse ethnic communities come together to celebrate the day. In Afghanistan Nowruz is generally celebrated by the northern people.

Qibla - is the direction that should be faced when a Muslim offers daily obligatory prayers.

Quran - the holy book revealed to the Prophet Muhammad by God. It consists of 114 chapters and is originally written in Arabic.

Shariah - an Islamic canonical law that is based on the Quran and Hadith but has jurisdiction over both religious and secular duties and prescribes the penalties for offences against such duties.

Shia - one of the two largest sects of Islam. Followers of this sect consider Prophet Mohammad's cousin and son-in-law, Ali and his descendants as the successors of the Islamic State (Khilafat) after Prophet Muhammad.

Ummah - an Arabic word meaning 'nation' or 'community'. In the Quran Ummah typically refers to a single group that shares common religious beliefs, specifically those that are the objects of a divine plan of salvation. 


\section{EXECUTIVE SUMMARY}

This research paper explores the role of social media as a medium of articulation of religiously-inspired radical ideologies and narratives in Afghanistan. The term 'radicalization' is used here to refer to processes of emergence and evolution of ideological and behavioral tendencies that are characterized by a shift towards intolerance and varying levels of predispositions towards violence. As a process, radicalization occurs at three levels: it begins with pendar (a shift in opinion), may continue with goftar (expression and propagation of intolerant and violent views) and might lead to kerdar (violent action). This study examines the role of social media at the goftar level of the process.

The study is qualitative in its approach and uses the following methods: 1) Monitoring and analysis of online contents of official social media profiles of religiously inspired militant groups as well as peaceful activist groups. This analysis is aimed to identify the main narratives and ideological trends that are spread by various Islamic activists and militant groups, and individuals. 2) Outline and analysis of a selected number of Taliban hymns used as mobile phone ringtones by the general public. These ringtones are analyzed as a form of social media with a previously unexplored potential role in radicalization. 3) Seventy-two semi-structured interviews with active social media users from the four cities - Kabul, Jalalabad, Herat and Mazar-e Sharif of Afghanistan. These interviews complement the analysis of online contents by providing detailed and geographically specific understanding of the way social media users approach and experience online extremist contents. These interviews aided researchers to extract clear narratives propagated by both extremist and more peaceful groups in Afghanistan.

\section{Main Findings}

First, militant groups such as the Taliban, Hizb-e Islami and the Islamic State (Daesh) extensively use social media as part of their broader information warfare against the Afghan government and its allies. Afghan militant groups appear to increasingly emulate the media-savvy Daesh in closely integrating social media in their broader information campaign strategies. The increase in online campaigns comes with a growing rivalry between these groups after the emergence of Daesh in Afghanistan during the first half of 2015.

Second, on $28^{\text {th }}$ of September 2015, the fall of the northern city of Kunduz in the hands of the Taliban demonstrated that social media is extensively being used by the insurgents as an instrument of information warfare for their campaign against the Afghan government and its international allies. In a few hours after the government forces retreated from the city, the news and pictures of the Taliban militants posing in the city centre reverberated instantly across Afghan social media networks. In addition to the announcement made by the Taliban spokesmen, the local Taliban members extensively used popular platforms like Facebook by posting selfies with ordinary citizens and sharing videos of their troops taking control of the city's main institutions. A shift in the focus of the insurgency towards more urban centres, where the vast majority of the country's internet users are located, will increase the significance of social media in the ongoing information warfare between the Afghan government and the insurgents. 
Third, social media platforms, particularly its features that facilitate instant messaging with imageries, play an important role in articulating and diffusion of ideological views and political narratives in the post-2001 Afghanistan. Despite significant differences in their narratives and strategies, both peaceful and militant Islamic groups mutually reinforce one another and converge on some of the important aspects of their ideological views and political narratives. There is a common belief central to the narratives of militant groups, such as the Taliban, Hizb-e Islami and Daesh that Afghanistan is an "occupied" country and the Afghan government is a "puppet" of foreign "invaders", "crusaders" or "occupiers". What follows from such narratives is a strategy of violence and subversion to overthrow the democratically elected Afghan government and expulsion of international troops from the country. These groups also combine these ideological positions with commentaries on popular frustrations with the Afghan government, such as concerns about corruption and poor governance. In contrast to the militant groups' narratives and strategies, the interviews and the content analysis show that a number of peaceful activist groups also use social media to actively disseminate strategic narratives which contribute to broader radicalization processes. These narratives focus on socio-cultural concerns, such as the perceived foreign cultural influences that include social and cultural liberalization and the status and rights of women in Afghanistan. While these groups do not directly advocate for armed and violent strategies, they contribute to a broader process of radicalization by disseminating various narratives that promote a popular perception of Afghanistan as being under "cultural invasion" and failing to condemn the violent tactics and strategies employed by the militant groups.

Fourth, while the focus of this study was on religiously-inspired radical narratives and ideologies, many interviewees pointed to other forms of radical narratives and ideologies, most notably extremist ethnonationalist and some secular views that also promote group hatred and intolerance through social media. Many respondents pointed to a spike of radical ethno-nationalist narratives and viewpoints in tandem with political polarization during the 2014 presidential election crisis.

Fifth, both militant and peaceful groups use special tactics in their social media campaigns to better reinforce their strategic narratives. It was found that anonymity and gender stereotypes are among the most frequent tactics used by these groups. For example, in addition to the official accounts apparently run by the organizations, many individual members and sympathizers use the opportunity provided by the internet to create anonymous accounts which are used to share, support and spread the contents of the official accounts of various radical groups. Gender stereotypes are also extensively used across social media platforms. For example, in their hymns, which are used as mobile phone ringtones in the rural parts of Afghanistan, the Taliban use gender stereotypes as a tool for social communication campaigns. The hymns stress on bravery and other manly characteristics for the defense of the country and associate those refusing to join their ranks with women, characterized by weakness and cowardice.

Sixth, individual users respond to radical narratives in social media in four different ways. One group of respondents openly challenges and confront messages disseminated by radical groups and/or individuals in social media. A second group of respondents preferred to challenge and confront radical messages coming from real and individually identifiable social media users only, while outlining the dangers of responding to radical contents of the anonymous accounts. A third group of respondents 
chose instead to ignore radical content altogether, believing that will decrease the popularity of radical groups in social media. Finally, a fourth group of respondents countered radical messages by promoting moderate views about religion, as well as cohesion and tolerance among the country's ethnic groups and religious sects by highlighting the dangers of extremism and intolerance as witnessed during the past several decades of war and conflict in Afghanistan.

Seventh, the diffusion of radical narratives occurs in the absence of a systematic counter-radicalization policy by the Afghan government. While there are important individual and civil society initiatives that aim to counter radical trends and promote a more inclusive and tolerant views, the Afghan government is yet to formulate a policy for countering radicalization more generally, and through social media more specifically.

\section{Recommendations}

Government of Afghanistan:

1. Initiate a broad consultation with relevant stakeholders, including Afghan civil society, and Islamic activist groups, religious leaders and educational institutions with the goal of formulating a counter-radicalization approach and policy. A future counter-radicalization policy should address broad strategic narratives that underpin radicalization as well as individual vulnerability and susceptibility to recruitment and mobilization by radical groups.

2. Broaden the scope of the current discussion on regulation of social media by engaging with civil society, educational institutions, Islamic activist groups and media organizations. A future legal and regulatory framework concerning social media should find a balance between regulation of social media and concerns about restrictions of freedom of expression.

3. Review the current procedure for registration of all mobile phone SIM-cards in order to make it easy for the relevant government agencies to track down the fake social media users disseminating radical narratives online. For this purpose, more cooperation and better coordination is required between the Afghan government and the companies providing internet services in Afghanistan.

4. Take immediate and coordinated initiatives to counter radical ethnic narratives and political polarization that intensified during the 2014 presidential election crisis. This must include the two political coalitions that formed the National Unity Government (NUG) in September 2014 as well as Afghan civil society groups and the media.

International Community:

1. Support the Afghan government in formulating a counter-radicalization policy by sharing the experiences of counter-radicalization and de-radicalization policies in similar fragile and conflict states, and providing advice on the best approaches to counter radical narratives in social media without jeopardizing the citizens' freedom of expression.

2. Support future researches on more specific aspects of radicalization processes in social media in the context of Afghanistan. These researches should focus on both the impact of macro-level 
narratives spread by the main radical groups and micro-level processes of recruitment of individuals via social media, particularly young people, by these same groups.

3. Support independent and civil society initiatives that aim to counter-radicalization and promote tolerance and coherence among the various religious and ethnic groups in Afghanistan. More specifically, consider supporting initiatives that can act as a bridge between Islamic activist groups and secular civil society organizations.

\section{INTRODUCTION}

In recent years, Afghanistan has experienced a dramatic boom in social media. The expansion of access to the internet across the country has provided the country's population with a new space and novel methods for communicating and connecting with one another and the outside world and expressing their views on a wide range of social, political and security issues. The instantaneous and personalized nature of the internet communication generally, and social media in particular, is likely to have farreaching consequences for the future political, social and security affairs of the country. In authoritarian contexts, some scholars see in modern Information and Communication Technology (ICT) a liberating potential that "can expand political, social and economic freedom." ${ }^{1}$ The internet-based platforms such as Facebook and Twitter may empower marginalized social and political groups, such as youth and women, and expose the society to powerful forces of globalization. The proliferation of modern communication technologies may also have significant social, political and security risks as shown by the adaptation of these communication technologies by radical and militant groups such as the Taliban and Daesh.

This research paper explores the role of social media in radicalization processes in Afghanistan. Specifically, it focuses on the role of social media in the articulation and diffusion of religiously inspired radical and violent narratives and ideologies. In addition to the internet-based technologies, the study also analyses the contents of a sample of Taliban hymns, which have assumed a significant communicative function as mobile phone ringtones in many parts of Afghanistan. While the study takes a broad approach towards radicalization as a relational, social and political process, it specifically focuses on religiously inspired groups and radicalization.

This paper is divided into five sections. The first section discusses the conceptual framework of the study, explaining how social media might contribute to radicalization as a social process. The second elucidates the research methods employed in this study. The third analyses the contents of a sample of Afghan social media contents and Taliban hymns used as mobile phone ringtones. The fourth discusses popular perceptions of the role of social media in radicalization in Afghanistan. Finally, the fifth section provides an overview of main findings of this research with a few main concluding remarks.

\footnotetext{
${ }^{1}$ Larry Diamond, 'Liberation of Technology', Journal of Democracy, 2010, Volume 21, Issue 3, Pages 69-83
} 


\section{CONCEPTUAL FRAMEWORK: Social Media and Radicalization}

The precise definition of social media continues to be debated. ${ }^{2}$ The phrase 'social media' is often used to refer to internet-based platforms that are characterized by instant and personalized communication and social interactions and instantaneous sharing and flow of information. In addition to the internetbased platforms such as Facebook, Google+, Twitter, Instagram, and YouTube, this study also uses the term 'social media' to refer to the mobile phone technologies, such as ringtones and Bluetooth because similar to social media these have been used in Afghanistan to share various content and information. This paper focuses on the contents of Taliban hymns, which in recent years have been used as mobile phone ringtones and shared through Bluetooth, making them significant and yet understudied medium of communication and sharing of information. YouTube, Twitter, Facebook and so on are used by more educated and urban groups whereas ringtones and Bluetooth are used more often by social groups which have limited access to sophisticated mobile phones and the internet. Ringtones and Bluetooth have been particularly useful for mobile social groups such as regular travelers or drivers, and as such are important means of communication in many parts of Afghanistan.

The recent expansion of access to the internet and modern communication technologies has provided the country's population a new 'virtual space' to express their views and communicate and connect with one another and the rest of the world. In 2001, the country had only 15,000 analogue telephones, which provided access to only 0.3 percent of the population. In 2014, there were 23.21 million mobile phone users in Afghanistan, and 3 million people (about 10 percent of the total population) had access to the internet, including 697,000 users who had subscribed to internet $3 \mathrm{G}$ services. ${ }^{3}$ With further expansion of $3 \mathrm{G}$ mobile services in 2015 , it is likely that the number of internet users would have further increased.

The ever-expanding social media market in Afghanistan has been dominated by Facebook. A recent study by GIZ, the German international development agency, estimated that in Kabul and the six Northern provinces covered under the study, $87.8 \%$ of the social media users had profiles on Facebook, followed by $12.9 \%$ on Google+, $5.8 \%$ on Youtube, and $3.8 \%$ on Twitter. ${ }^{4}$ The GIZ study also offers insights into the profiles of active social media users in Afghanistan. Of the sample covered by the study, $67.9 \%$ users had university degrees, and $62.1 \%$ spoke English. Furthermore, the majority of users were employed (63.4\%) and a significant proportion of them were students (21.6\%). Significantly, for $62.1 \%$ users, English was the main medium of communication, followed by Dari (30.1\%) and Pashto (3.3\%). ${ }^{5}$ While the overall number of social media users remains a minority (about 9 percent of the population), the active users are more likely to be better educated, politically informed, and socially mobile individuals with greater capacity to shape the opinion of the rest of the society.

\footnotetext{
${ }^{2}$ Caleb T. Carr \& Rebecca A. Hayesa, 'Social Media: Defining, Developing, and Divining', Taylor Francis Online, 2015, http://www.tandfonline.com/doi/abs/10.1080/15456870.2015.972282

${ }^{3}$ Telecom Sector's Recent Achievements, Official Website of the Ministry of Telecommunication and Information Technology (MCIT), http://mcit.gov.af/en/page/4876/6005, Accessed on October 27, 2015

${ }^{4}$ Social Media in Afghanistan: Measuring the Usage \& Perceptions of the Afghan Population, GIZ, Kabul, 2014, http://ez-afghanistan.de/fileadmin/content/news/Social_Media_251114.pdf

${ }^{5}$ lbid
} 
Consequently, social media platforms function as major mediums of communication as well as tools for social and political mobilization. For example, in March 2015 a young Afghan woman, Farkhunda, was lynched by a mob in Kabul after she had an argument with a religious official at the Shah-e Doshamshirah shrine. Some government officials as well as some of the religious figures almost immediately justified her killing on social media, but on the following day, when the details of the incident became clear, several hundred citizens including, women took to the streets of Kabul in protest. The speed of this relatively unusual mobilization and the role of both women and government officials in the Facebook-driven discourse surrounding it suggested the influence of social media in this striking event. Similarly, during the 2014 Afghan presidential elections social media, for the first time, assumed a vital role and served as a virtual venue for election campaigns and heated debates among the supporters of the leading candidates.

The dramatic boom in social media across Afghanistan has met with mixed responses thus far. Some analysts have pointed to the empowering effect of social media for marginalized social groups such as the youth and women. ${ }^{6}$ Others have expressed various concerns regarding the negative socio-political impact of the virtual platform, most notably its exploitation by radical and militant groups. As mentioned earlier, this research paper explores the role of social media in the articulation and the diffusion of radical and violent narratives and ideologies in Afghanistan. This paper begins by providing a snapshot of the current debate about radicalization and how it might benefit from the expansion of social media.

\subsection{Radicalization as a relational process}

The word 'radical' when it is used to describe individual groups and 'radicalization' the process, whereby they become the object of such description, can carry potentially controversial meanings and consequences. ${ }^{7}$ Post September 2001 terrorist attacks on the US, these terms have become catchwords of studies on terrorism and counterterrorism policies focusing on radical Islamic groups and individuals. In the words of Arun Kundnani, "the concept of radicalization has become the master signifier of the late 'war on terror' and provided a new lens through which Muslim minorities are viewed in Western societies. Such narrow application of the concept to some particular Islamic militant groups can potentially limit the understanding of the broader socio-economic and political processes that drive individuals and groups towards extremist and violent ideologies and behaviors.

Having said that, radicalization can be used to explain the frequent ideological and behavioral tendencies around the world that are characterized by a shift towards intolerance, and varying levels of

\footnotetext{
6 Joshi Herrmann, How Social Media is Empowering Young Afghan Women: The Facebook Effect, The Independent, February 10, 2015, http://www.independent.co.uk/life-style/gadgets-and-tech/features/how-social-media-isempowering-young-afghan-women-the-facebook-effect-10375022.html

7 Peter R. Neumann, The Trouble with Radicalization, Chatham House, July 2013, https://www.chathamhouse.org/publications/ia/archive/view/193091

${ }^{8}$ Arun Kundnani, 'Radicalization: The Journey of a Concept', Race \& Class, 2012, http://rac.sagepub.com/content/54/2/3.short?rss=1\&ssource=mfr
} 
predispositions towards violence. In this research, radicalization is conceived as a dynamic ideological and behavioral shift that occurs in a relationship between individuals and groups as they compete and interact with one another, as well as their social and political environments. Consequently, this paper emphasizes on the inter-group dimension and partly draws on the work of Della Porta ${ }^{9}$ to view radicalization as a 'relational process' that impacts how individuals and groups view one another. Radicalization as a 'relational process' always involves at least two actors that are engaged in some sort of 'conflictual relationship'. Therefore, radicalization as a phase of 'conflictual relationship' between groups occurs when the parties to a conflict become increasingly intolerant towards each other, develop uncompromising attitudes, and show a readiness to take violent action in support of their own positions.

In this broad broach, all forms of groups and actors -including state and non-state actors, leftists, liberals, conservatives as well as secular and religious groups - can experience radicalization as they interact with one another and their broader social and political environment. A key implication of this approach is that the extremist groups inspired by religion are only one of the several types of the same phenomenon, even though they are the subjects of most of the current policies and scholarly debates. Thus, while this research paper focuses on radical currents that purport to be inspired by religion, the definition adopted can be extended to other groups that are inspired by other forms of ideologies and worldviews.

The exact processes and pathways leading to radicalization are still being debated. However, radicalization as a process entails some broadly shared characteristics. It begins with a 'cognitive shift', which is when individuals and groups are attracted to extreme, intolerant and violent views, and may lead to behavioral changes, characterized by a propensity towards violent tactics and strategies. In other words, it begins with a change in pendar (shift in opinion), continues with goftar (expression and propagation) and might lead to kerdar (violent behaviors). For example, radicalization among Afghanistan's university students is characterized by a shift from usual academic debates in classes towards various forms of activism and protest activities as student groups interact with one another, their administration and faculty members, and the broader social and political environment of the country. ${ }^{10}$

Radicalization as a process occurs at three different levels: the individual, the group and the masses. Combined together, these different levels of radicalization form a pyramid, at the bottom of which many groups and individuals might share a common pendar, shared beliefs and feelings, but the relatively smaller number reaches the apex, whereby they gain a readiness to take action in support of their shared beliefs. Therefore, the pendar and kerdar aspects of radicalization constitute the top and the base of a pyramid, with many groups in the middle, experiencing radicalization at the goftar level. The main point

\footnotetext{
9 Della Porta, 'Guest Editorial: Processes of Radicalization and De-Radicalization', International Journal of Conflict and Violence, 2012, http://ijcv.uni-bielefeld.de/index.php/ijcv/article/view/266

10 Robert Zaman \& Abdul Ahad Mohammadi, Trends in Student Radicalization across University Campuses in Afghanistan, Afghan Institute for Strategic Studies, Kabul, October 2014, http://www.aiss.af/wpcontent/uploads/2015/09/English-version-Trends-in-Radicalization-across-Unregistered-Madrassas-inAfghanistan.pdf
} 
is that radicalization is not an everlasting and inherent quality of individuals and groups. These groups and individuals can potentially radicalize and de-radicalize as they interact with different environments and respond to the strategies and tactics of other groups.

The pertinent question here is that what drives individuals to move from the base of the pyramid to its top i.e., a shift from the radical pendar to radical kerdar. McCauley and Moskalenko ${ }^{11}$ propose a number of mechanisms that are at work when this shift occurs:

Table 1: Levels and Mechanisms of Radicalization Source: McCauley and Moskalenko, 2008

\begin{tabular}{|c|c|}
\hline Levels of Radicalization & Mechanisms \\
\hline \multirow[t]{4}{*}{ Individual } & 1. Personal victimization \\
\hline & 2. Political grievance \\
\hline & 3. Joining a radical group - the slippery slope \\
\hline & 4. A radical group - the power of love \\
\hline \multirow[t]{3}{*}{ Group } & 5. Extremity shift in like-minded groups \\
\hline & 6. Extreme cohesion under isolation and \\
\hline & threat \\
\hline \multirow[t]{6}{*}{ Masses } & 7. Competition for the same base of support \\
\hline & condensation \\
\hline & 9. Within group competition-fissioning \\
\hline & 10. Jujitsu politics \\
\hline & 11. Hate \\
\hline & 12. Martyrdom \\
\hline
\end{tabular}

At the basic level, radicalization entails a feeling of victimization and political grievance for which other groups or individuals are deemed to be responsible. The dynamics of the process change when individuals join radical groups or form new ones. Once groups are formed, new dynamics pushes the radicalization process. Group membership becomes part of individual members' identities and a source of love and collective belonging. Groups exert pressure on members to conform to its norms and ideals and overcome internal competition and fissures. Externally, groups may also radicalize as they respond to the external threats coming from the state and non-state actors. Sometimes, groups may also engage in jujitsu politics, whereby they deliberately elicit a response from the state that antagonizes broad segments of their society and consequently increases the number of sympathizers and supporters of the group. At the most extreme level, groups subscribe to ideologies of hate and self-sacrifice, as demonstrated by the recent upsurge in suicidal attacks by many militant groups, such as the Taliban, AlQaedah, and Daesh.

\footnotetext{
${ }^{11}$ Clark McCauley \& Sophia Moskalenko, 'Mechanisms of Political Radicalization: Pathways towards Terrorism',
} Taylor Francis Online, 2008, http://www.tandfonline.com/doi/abs/10.1080/09546550802073367 
In the context of Afghanistan, various combinations of these mechanisms might be responsible for the new wave of radicalization and extremist violence that followed the US-led NATO intervention in Afghanistan in 2001. This research is primarily focused on the goftar and discursive aspects of radicalization, and articulation of broad strategic narratives that include identification of grievances and problems as well as possible courses of actions, including the most extreme behaviors, such as suicide attacks. Central to the resilience of Afghanistan's post-2001 militant groups and their ability to maintain a support base are strategic narratives that combine religiously inspired ideologies with the articulation of individual and collective grievances and frustrations with the Afghan government and its international allies. As shown below in Table 2, a distinction is made between radical goftar and radical kerdar, the base and apex of the pyramid respectively. The kerdar aspect of the process is illustrated by the armed insurgency of militant groups, such as the Taliban, the Haqqani Network and the militant faction of Hizbe Islami against the Afghan government and the international military forces. At the goftar level, radicalization as a process is also facilitated by ideological, social and political narratives, which are articulated by other groups and individuals that do not directly engage in the armed insurgency.

Table 2: Levels and characteristics of radicalization in post-2001 Afghanistan

\begin{tabular}{|c|c|}
\hline Levels of Radicalization & $\begin{array}{l}\text { Characteristics of Radical Narratives and } \\
\text { Behaviors }\end{array}$ \\
\hline $\begin{array}{l}\text { Radical Goftar (Spreading and articulating radical } \\
\text { ideologies) } \\
\text { Radical Kerdar (Readiness to take violent action) }\end{array}$ & $\begin{array}{l}\text { 1. Ideological opposition to the } \\
\text { democratic and peaceful political } \\
\text { process, enshrined in the } 2004 \\
\text { constitution of Afghanistan; } \\
\text { 2. Narratives of victimization of the } \\
\text { Afghan people by the international } \\
\text { military forces and the Afghan } \\
\text { government; } \\
\text { 3. Behavioral readiness to take violent } \\
\text { and subversive actions to overthrow } \\
\text { the political order in the country; } \\
\text { 4. Intolerance towards existence and } \\
\text { expression of alternative views by } \\
\text { other social and political groups that } \\
\text { do not share the narratives of } \\
\text { insurgents. }\end{array}$ \\
\hline
\end{tabular}

Consequently, at the top of the radicalization pyramid are the militant organizations, such as the Taliban, Hezb-e Islami, Al-Qaedah and more recently Daesh. However, other groups and individuals may also contribute to the radicalization process by spreading extremist, violent and intolerant views without directly engaging with the armed insurgency. Hence, radicalization also benefits from the work of groups that accentuate public sympathy and support for the violent armed groups at the bottom of the pyramid. 


\subsection{Social media as an instantaneous, interactive and personalized means of communication}

Militant groups, such as the Taliban have long been recognized for their engagement in cyberspace as a new battlefield. In Afghanistan, the Taliban has latched on to the opportunity created by the expansion of internet access in recent years, in order to establish an effective presence in the virtual world. Their online presence and communication network was so effective that in 2012, it was believed that their "use of social media has outpaced that of NATO's and the US forces'."12 The Taliban even specifically established a 'media committee' to oversee and coordinate its online information campaign through several websites; Twitter and Facebook accounts; and YouTube channels. ${ }^{13}$

More recently, the militant group Daesh has adapted a particularly aggressive and sophisticated virtual communication strategy. The group has been so aggressive in its cyber strategy that in June 2015, it has been reported that an internal assessment of the US State Department concluded that the 'Daesh's violent narrative - promulgated through thousands of messages each day - has effectively "trumped" the efforts of some of the world's richest and the most technologically advanced nations'. ${ }^{14}$ The Brookings Centre for Middle East Policy estimated that between $4^{\text {th }}$ of October and $27^{\text {th }}$ of November 2014, there were some 46,000 Daesh accounts only on Twitter. ${ }^{15}$

Most of the concerns about the exploitation of social media by the militant groups often fail to reflect on the specific features of the militants' cyber strategy and do not address whether and how these militant groups have an advantage over others in exploiting these forums. While the precise of the definition of social media continues to be debated, ${ }^{16}$ this paper emphasizes its instantaneous, interactive and personalized features as a channel of mass communication. Awan ${ }^{17}$ suggests that the Jihadi virtual media serve four interrelated functions that include news, propaganda, training and expression. Jihadist groups use the virtual forums to spread the news of their activities, spread their ideology, share and disseminate practical organizational and training manuals, and finally online forums also serve as a conduit for nonviolent expression of anger and frustration.

\footnotetext{
12 Bill Gertz, Inside the Ring: Taliban infiltrate social media, The Washington Times, August 22, 2012 http://www.washingtontimes.com/news/2012/aug/22/inside-the-ring-taliban-inflate-social-media/?page=all

${ }^{13}$ Bashir Ahmad Gwakh, The Taliban's Internet Strategy, Radio Free Europe Radio Liberty, September 9, 2011, http://www.rferl.org/content/the_talibans_internet_strategy/24323901.html

${ }_{14}$ Mark Mazzetti \& Michael R. Gordon, ISIS Is Winning the Social Media War, U.S. Concludes, The New York Times, June 12,2015, http://www.nytimes.com/2015/06/13/world/middleeast/isis-is-winning-message-war-usconcludes.html?_r=0

15 J. M. Berger \& Jonathan Morgan, The ISIS Twitter Census: Defining and Describing the Population of ISIS Supporters on Twitter, Brookings, March 2015, http://www.brookings.edu/research/papers/2015/03/isis-twittercensus-berger-morgan

${ }^{16}$ Caleb T. Carr \& Rebecca A. Hayes, 'Social Media: Defining, Developing, and Divining', Taylor Francis Online, 2015, http://www.tandfonline.com/doi/abs/10.1080/15456870.2015.972282

17 Akil N. Awan, Radicalization on the Internet? The Virtual Propagation of Jihadist Media and its Effects, RUSI, June 2007, https://www.rusi.org/publications/journal/ref:A46728254DE4AE/\#.VhzkAuyqpHw
} 
Similarly, Ingram ${ }^{18}$ provides an analytical account of how Daesh's information warfare is intimately connected to and aligned with its political and military activities. He identifies three specific features of the group's information operation. First, Daesh has adopted a multi-dimensional approach to disseminate its information to maximize its reach, relevance and resonance with local, regional and global audiences. Second, the information campaign is intimately synchronized with its actual political and military actions and lastly it has demonstrated a 'deep strategic appreciation for its 'brand' as a symbol of its narrative and action. ${ }^{.19}$

The focus on technology-savvy violent groups seem to have pushed to the sideline a more sanguine view of modern communication technologies that comes from the studies of peaceful and progressive social movements. In contrast to the grim view coming out of the studies of terrorism and counterterrorism policies, scholars of social movements have focused on the liberating and empowering functions of modern communication technologies. For example, Milan ${ }^{20}$ saw in modern technology a 'stolen fire', a Prometheus stealing fire from the gods and a liberating potential to create new 'ways of social organizing seeking to create alternatives to existing media and communication infrastructure. ${ }^{21}$

How can these two views be reconciled? An important starting point is to explore the causal mechanisms of the impact of the internet on politics. Farre ${ }^{22}$ identifies three such broad causal mechanisms through which the internet broadly contributes to political polarization in the US: 'lowering of transaction costs', 'homophilous sorting', and 'preference falsification'. Such mechanisms might also be at work in radical and militant as well as peaceful and progressive groups. The worldwide expansion of the internet and modern communication technologies has greatly lowered the costs of social transaction, making it affordable and faster to communicate with others and organize instantly. Second, as in social life generally, there is a tendency among internet users to cluster in groups of like-minded people. This means the internet makes it easier for individuals who share interests to contact one another, and share information and ideas through online forums. Third, the internet reduces the prospect for 'preference falsification' that is the tendency of individuals to conceal their true preferences. Since, the internet provides a variety of venues for expression and facilitates faster flow of information; individuals are more likely to express their genuine social and political preferences.

\footnotetext{
${ }^{18}$ Haroro J. Ingram, Three Traits of the Islamic State's Information Warfare, RUSI, December 2014, https://www.rusi.org/publications/journal/ref:A54AAAB6F80360/\#.VhznlOyqpHw 


\section{RESEARCH APPROACH AND METHODOLOGY}

This study explores the role of social media as a tool for expressing and diffusing radical narratives and ideologies. Social media as a medium of communication is distinguished for it facilitates fast, personalised and low-cost flow of information. As a result of this, there is enough evidence to conclude that the radical and militant groups exploit these features of social media to communicate their messages to a larger audience.

The research began on $15^{\text {th }}$ of February 2015 and concluded on $31^{\text {st }}$ of July 2015. It began with a series of discussions with the AISS' international academic advisors and national scholars, civil society members and independent researchers. The most significant of these discussions were the two roundtables held in Kabul. The first roundtable discussion was held on 15 th of March 2015 in Kabul. The primary objective of the event was to present the preliminary research concept and methods of the project to a group of Afghan and international experts and get their feedback on its overall direction and methodological approach. The comments and feedback provided by the participants were used to clarify and improve the research concept and methodology. The second roundtable was held in Kabul on the $20^{\text {th }}$ of September 2015. During this roundtable, the research team presented the findings of the research and requested the participants to critically reflect on different aspects of the findings and provide additional comments on how to substantiate the findings. The research team also used the opportunity to ask questions to the participants about potential gaps and grey areas in the research.

Initially, the research team considered a mix of qualitative and quantitative methods, but after the consultation processes, the team decided to take a qualitative approach for two reasons. Since it is a first study of its kind in Afghanistan, it was found that there were no reliable figures of active social media users from which a representative sample could have been drawn. Therefore, while selecting the appropriate sample for quantitative study, the research team experienced the usual problem of online research that results from the lack of 'population estimates'. ${ }^{23}$ The problem of selecting a representative sample became apparent during the initial study of social media accounts of radical groups, as most accounts could not be plausibly linked to specific groups or were regularly removed or recreated under different names. It was also concluded that an initial qualitative study could help identify the main radical narratives, which can be subsequently used for quantitative studies. Therefore, the study did not seek to produce new quantitative figures about radicalization and social media in Afghanistan. It only aimed to achieve two specific objectives: First, whether and how radical narratives are being disseminated through social media and second, how active social media users respond to those narratives.

To achieve these objectives, the following methods were employed in this research: a) monitoring and analysis of online contents of official social media profiles of religiously inspired radical and militant groups; b) collection and analysis of a selected number of Taliban hymns used as mobile phone ringtones by the general public; and c) 72 semi-structured interviews were conducted with active social media users, including journalists, social media activists, Afghan governmental officials, researchers,

23 Jennifer Earl, 'Studying Online Activism: The Effects of Sampling Design on Findings', Mobilization, 2013, http://www.mobilization.sdsu.edu/articleabstracts/184Earl.html 
scholars, students and other relevant authorities, in four cities of Afghanistan - Kabul, Jalalabad, Herat and Mazar-e Sharif. The next section provides further details about these methods.

\subsection{Monitoring and analysis of social media contents}

Between $15^{\text {th }}$ of February 2015 and $31^{\text {st }}$ of July 2015, the research team continuously monitored the online contents of a selected number of official social media profiles of radical and militant groups. In line with the specific focus of this research on drivers of Islamic radicalization, the team focused on the social media profiles of religiously motivated violent and non-violent groups, and individuals. ${ }^{24}$

The research team utilized a snowball sampling method, beginning with a purposive selection of social media profiles of the active and well-known individuals and organizations. The primary list was used to identify and follow social media profiles of a range of other organizations and individuals by following the shared content and connections across the online forums.

The preliminary list included the official social media profiles of the Taliban, Hizb-e Islami, Jamiat-e Eslah, Hizbut-Tahrir Afghanistan, and a number of other lesser known individuals and organizations. It is worth mentioning that the militant faction of Hizb-e Islami and the Taliban are actively participating in an armed insurgency against the Afghan government. On the contrary, Jamiat-e Eslah is a formally registered organization with the Afghan government with no established connections with the insurgency. Hizbut-Tahrir Afghanistan is not a legal entity in Afghanistan, but it does emphasize its commitment to non-violent social and political actions.

During the monitoring process, it was analyzed that how these groups and activists responded or chose not to comment on current social, cultural and political affairs as they emerged in Afghanistan and abroad. The review was guided by two specific questions. First, the research team followed the account updates of these groups to identify the main social, political and religious issues or current incidents that were being debated, as well as the political and ideological narratives that were being formulated and propagated. Second, the research team noted that whether the radical groups' proposed actions and strategies advocate for violence to address grievances.

\subsection{Collection and analysis of a selected number of Taliban hymns used as mobile phone ringtones}

This component of the research has used a sample of popular Taliban hymns used as mobile phone ringtones, mostly in the rural areas of Afghanistan. These hymns are shared via Bluetooth in these areas; however, such hymns are also available on various social media platforms. This section seeks to explain how Taliban uses these hymns for propaganda against the Afghan government and its international allies, apart from increasing sympathy for their movement among the masses.

24 The religiously motivated violent groups consist of the Taliban and Hizb-e Islami where as, the religiously motivated non-violent groups consist of Hizbut-Tahrir and Jamiat-e Eslah. The social media profiles (Facebook, YouTube and Twitter) of both violent and the non-violent groups were monitored during this study. Additionally, some YouTube accounts belonging to individuals promoting radical ideas were also monitored, which include Paymanfilm Co, PayameHaq, Rashed Muslim, Khorasan Taghot Shekan and so on. 


\subsection{Semi-structured interviews}

To complement the analysis of online and ringtone contents, a total of seventy two semi-structured interviews were conducted in Kabul, Mazar-e Sharif, Herat and Jalalabad. The interviews were conducted in July and August 2015 with a primary objective to collect a broad sample of perceptions and opinions about the role of the social media in Afghanistan. The interview questions were formulated in consultation with the AISS' academic advisors and pilot testing was done through ten primary interviews in Kabul and Jalalabad. These adequately tested questions were used by the AISS' field researchers in the provinces. The respondents were chosen from among the known active social media users, Afghan government officials, academicians, students, journalists and civil society activists.

\section{STUDY FINDINGS}

\subsection{Radical groups' objectives and tactics in social media identified}

Broadly speaking, the radical groups and individuals use social media in two ways. First, they use it to distribute and share materials from more traditional online sources such as websites run by organized groups. A number of articles and commentaries published on the websites of activist and militant groups are shared through official social media profiles of these organizations. Second, individual members or sympathizers use their own personal profiles to share the materials of their organizations and often adding their own commentaries. The former is easy to follow as it represents the views and positions of those organizations on a regular basis. However, the sharing of online contents by individual members or sympathizers seems to have a double effect: on one hand, they tend to make the content available to a larger audience, but on the other it represents a wide span of online constituencies with weak or little commitment to the main organizations. For the purpose of this study, this may mean that a significant number of social media users may occasionally share certain content of militant organizations without any active and long-term commitment to their broader goals and ideologies.

Consequently, it is important to make an important distinction between the goals and motivation of militant organizations and peaceful activists and organizations in their use of social media. The militant groups such as the Taliban use social media as part of their overall political and military strategy, whereas peaceful organizations such as Jamiat-e Eslah use social media as part of their strategy for

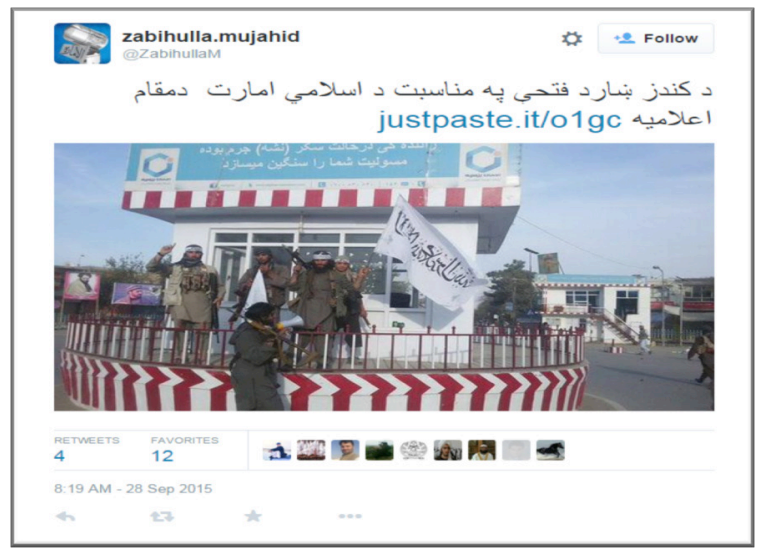

Screenshot 1 - A tweet posted by Zabiullah

Mujahid, a Taliban spokesman, about the takeover of Kunduz province by the Taliban peaceful social and cultural changes. It was noticed that the militant groups utilize social media for a variety of purposes that includes spreading news of respective political and military campaigns, demoralizing and delegitimizing the Afghan government and other non-state rivals, celebrating jihad 
and the mujahedin, and articulating narratives of victimization of Muslims generally, and the people of Afghanistan more specifically.

The manner and the purposes for which militant groups use social media became apparent during the Taliban takeover of the northern city of Kunduz in September 2015. It was found that over a week before the offensive, the Taliban used social media to spread the news of an "approaching victory" and a major "surprise". Following the establishment of Taliban control in the city, a Taliban commander reportedly used social media to pass instructions to his subordinates to take control of hospitals in the area. ${ }^{25}$ The news of the city's collapse also spread first through social media networks, as Taliban militias posted selfies with doctors at the provincial hospital and at major roundabouts and buildings in the city. The news of the fall of the city with instant photos shared through social media reverberated across the country, making the Taliban takeover of Kunduz a reality for the country's urban population. ${ }^{26}$ Global dissemination of photos and text messages related to the collapse of a major Afghan city via Facebook and Twitter served to communicate primary source relating to the event. The news of the capture of Kunduz, spread with instant images through social media, dawned upon the urban population of the country that the fall of major urban centers to the Taliban was a reality.

It was also observed that the militant groups employ specific tactics in their social media campaign. These include employment of gender stereotypes, extensive creation of fake accounts, and personalized recognition of their members' participation in military operations. Militant groups (see below the section on Taliban hymns) were found to emphasize on stereotypical masculine characteristics such as bravery and sacrifice for recruitment purposes, associating those who refuse to join their ranks with what they regard as feminine stereotypes such as cowardice. By contrast, non-militant groups such as Jamiat-e Eslah were found to be more concerned with western and secular cultural influences that might change gender relations in the country (See below the section on socio-cultural concerns).

\footnotetext{
${ }^{25}$ Borhan Osman, The Fall of Kunduz: What Does This Tell us About The Strength of Post-Omar Taliban? Afghanistan Analysts Network, September 30, 2015, https://www.afghanistan-analysts.org/the-fall-of-kunduz-whatdoes-it-tell-us-about-the-strength-of-the-post-omar-taleban/ ${ }^{26}$ Asef Maruf, Jabh-e Jang-e Tablighati-e Taliban (Taliban's Propaganda War Front), BBC Persian, October 2, 2015,http://www.bbc.com/persian/afghanistan/2015/10/151002_taliban_propaganda_war_asif_maroof
} 
Throughout the research, it became apparent that the militant as well as the non-militant groups extensively use anonymity as a tactic. Anonymous accounts, which were also described by the interviewees as Ja'ali or fake accounts come chiefly in two forms. First, a user creates an account under a common name without posting his or her own photos or any other personal information. Second, many users use generic, vague and unidentifiable titles such as Khwarahn-e Musalman (Muslim Sisters), ${ }^{27}$ a Facebook page that spreads Islamic messages with a special focus on its own interpretation of ideal Muslim women. Other such accounts are Tanzim-e Islami Zanan-e Afghanistan (Islamic Organization of Afghan Women) ${ }^{28}$, or Mujahide Afghan. ${ }^{29}$ Some accounts use titles that have ideological connotations such as Democracy Nezam-e Kofri (Democracy is an infidel system);

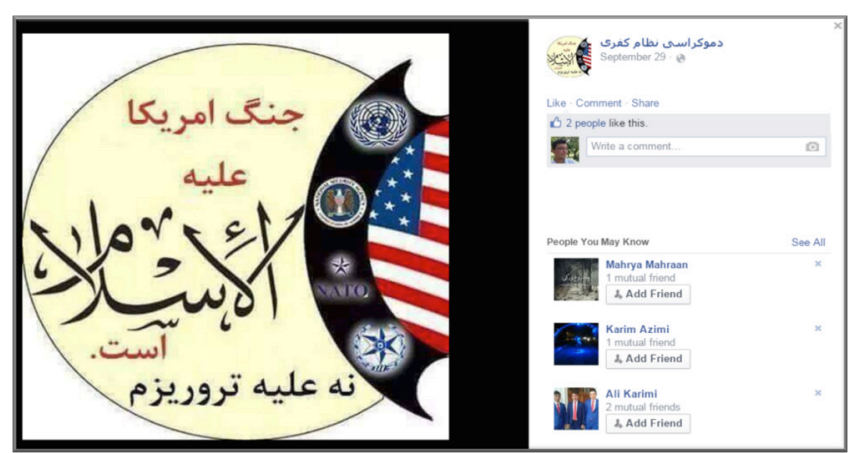

Screenshot 2 - A fake Facebook account named 'Democracy Nizam-e Kufri' (Democracy is an infidel system) claiming the US war on terror is actually against Islam not terrorism a Facebook account that seemed to be run by a supporter of Hizbut-Tahrir in Afghanistan. ${ }^{30}$ In September 2015, some Afghan politicians claimed that foreign elements were manipulating Afghan national interests. One senator claimed that 8,000 fake accounts are active on social media and are promoting division, and ethnic and sectarian conflict in Afghanistan. ${ }^{31}$

A third significant tactic is related to the use of one of the features of social media such as sharing of photos with precise commentaries to give highly personalized and heroic recognition to prominent members or those who die in battles with the Afghan or the international security forces (See the case of Azim Khan in the Taliban hymns section). While the process to motivate an individual to join militant groups involves multiple social and individual factors, the heroic and personalized recognition accorded to sacrifices by individual members are meant to create role models with whom other members of the society identify themselves.

\subsection{Main narratives articulated through social media in Afghanistan}

The role of social media is not merely limited to information warfare during certain specific episodes of armed conflicts such as the September 28 takeover of Kunduz. It has been found that social media is used to articulate specific ideological, political and socio-cultural narratives that provide the necessary

\footnotetext{
${ }^{27}$ Khahar-e Musalman, Facebook Page, Accessed on October 6, 2015

28 Tanzim-e Islami Zanan-e Afghanistan, Facebook Page, Accessed on October 6, 2015

${ }^{29}$ Mujahed-e Afghan, Twitter Page, https://twitter.com/mujahidafghan, Accessed on October 6, 2015

30 Democracy Nezam-e KofriAst, Facebook Page, Accessed on July 22, 2015

${ }^{31}$ Khwaja Basir Fitri, 8,000 Facebook Accounts Created to Divide Afghans, Pajhwok Afghan News, October 6, 2015; Fareshta Neda, Mokhalefan Ba Ejad-e Safahat-e Jaalidar Facebook Mian-e Afghanha Tafriqa Andazi Mikunand (The Opposition Uses Fake Facebook Pages to Create Divisions Among Afghans), Radio Azadi, October 7, 2015,http://da.azadiradio.org/content/article/27292802.html
} 
moral support and political justification to the insurgency and other forms of violence. While unraveling these narratives, it was found that there are significant similarities and differences between the militant and peaceful Islamic groups. In contrast to the militaristic focus of groups such as the Taliban, peaceful groups focus more on narratives of foreign social and cultural influences in post-2001 Afghanistan. Both groups reinforce a common narrative, albeit the former focuses on foreign political and military influences, while the latter on perceived negative impacts of alien cultural influences.

The monitoring of selected social media accounts highlighted the issues of importance and current affairs discussed the most in Afghanistan. A total of 124 commentaries were found that covered a wide range of political, social, military and cultural aspects of Afghan society. The following 5 categories were the dominant themes of discussions across the monitored accounts:

1. Legitimacy and credibility of the Afghan government

2. The presence of foreign troops in Afghanistan, the Bilateral Security Agreement (BSA) with the United States and civilian casualties.

3. Socio-cultural issues: Foreign cultural influence, the role of women and the nature of civil society in Afghanistan

4. Strategies for social, political and military action: War, jihad and suicide bombings

5. Islamic Ummah affairs

The online contents analyzed helped in unearthing the main radical narratives that constitute the goftar or discursive aspects of radicalization. These narratives were articulated in response to some particular aspects of the contemporary affairs and incidents. While primarily focusing on discursive aspects of radicalization, the analysis of these narratives also contribute to the understanding of the kerdar aspects of radicalization by highlighting the solutions and strategies proposed by these groups for addressing the problems they are most concerned about. The research paper specifically observed how these problems were identified and what aspects of the problems were stressed upon and more importantly, which social and political actions - violent or peaceful - were formulated as a means to address such specific grievances. The identification of problems is at the core of radical political and ideological narratives. While many groups share common grievances and identify the same or similar problems that they are most concerned about, for example the lack of legitimacy of the Afghan government and/or electoral democracy. However, these groups diverge in respective strategies needed to address those problems. Hence, only some of these groups reach the third level of radicalization i.e. radical kerdar, characterized by a propensity to join armed insurgency against the government. As noted by McCauley \& Moskalenko, ${ }^{32}$ radical groups at any of the three different levels of the radical pyramid may contribute to a broader process of radicalization by diffusing and formulating radical narratives and ideologies in an effort to outperform other rival groups. Taking this into consideration, the subsequent section provides a detailed analysis of the earlier mentioned five themes.

${ }^{32}$ Clark McCauley \& Sophia Moskalenko, 'Mechanisms of Political Radicalization: Pathways Towards Terrorism',
Taylor Francis Online, 2008, http://www.tandfonline.com/doi/abs/10.1080/09546550802073367 


\subsubsection{Legitimacy and credibility of the Afghan government}

Militant groups such as the Taliban and the armed wing of Hizb-e Islami that lead the current insurgency in Afghanistan have a clear and consistent view on the post-2001 political process in Afghanistan, i.e., the country is occupied by foreign invaders and the Afghan government is a puppet regime. What follows from this problem identification is a strategy of armed insurgency to overthrow the Afghan government and expel foreign forces. However, there are a number of other Islamic activist groups that draw the idea from insurgents that the country is 'occupied' and the Afghan government is a 'puppet' and also agree with an armed insurgency strategy to overthrow the government. This coherence of views is also broadly reflected in social media profiles of both militant and non-violent activist groups.

Since, the Taliban and the militant Hizb-e Islami consider the Afghan government as a 'puppet', they also consider those who work for government and collaborators as their enemies. Therefore, they may be justifiably attacked. For example on $4^{\text {th }}$ of May 2015, the Taliban posted a message on its official Facebook page (next to the pictures of the dead bodies of Afghan security forces apparently killed by the Taliban) stating that "the Islamic Emirate of Taliban calls upon all soldiers and police forces of Afghanistan not to sacrifice themselves for the gloomy cause of Americans. No one should sacrifice

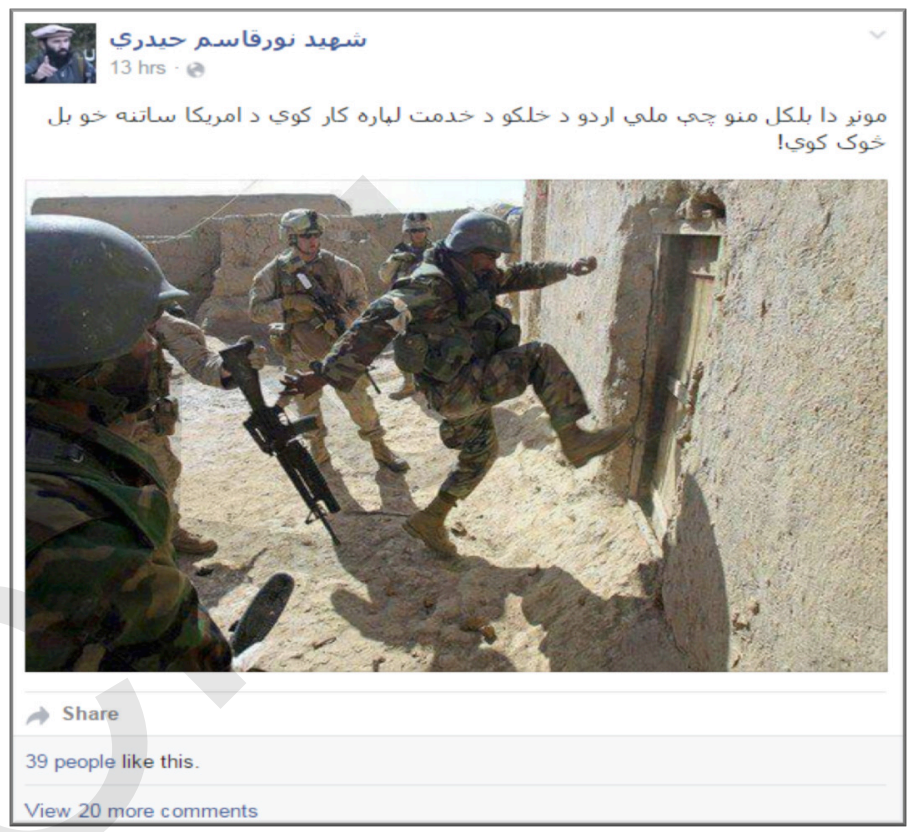

Screenshot 3 - A post by a Taliban sympathizer on Facebook with the message, 'Afghan National Army works for America' themselves to protect some corrupt and puppet figures who own palaces in Dubai, America and other Western countries." ${ }^{33}$

On some occasions, the social media accounts under observation urged members and sympathizers of the Afghan government to resign. For example, on 23 $3^{\text {rd }}$ of June 2015, Hizb-e Islami posted an article on Facebook, titled: "Should members of Hizb-e Islami in governmental positions resign?" Referring to some of the members ${ }^{34}$ of Hizb-e Islami who work with the Afghan government, the author calls upon "the Hizb-e Islami members to get rid of this unstable and inefficient government. It is just your names that are being misused as you are not involved in the decision making and they do not care about your

\footnotetext{
${ }^{33}$ Alemarah, Taliban's Official Facebook Page, Accessed on May 4, 2015

34 Qutbud-din Hilal, a candidate in the 2014 presidential elections; Muhammad Khan, the current deputy of the Chief Executive Officer (CEO) of Afghanistan; Hadi Arghandival, the former minister of economy; and Khalid Faruqi, a leader of a registered wing of the Hizb-e Islami
} 
ideas ... this is a corrupt government, in fact the most corrupt government in the world, which is made up of traitors, hypocrites and thieves. ${ }^{\prime 35}$

Hizbut-Tahrir is the only significant group that holds views similar to that of the Taliban and shares Hizbe Islami's opinions on the credibility and legitimacy of the Afghan government. Hizb-e Islami is a transnational organization that has been active in Afghanistan since 2003. It proclaims to pursue a nonviolent strategy for the revival of Caliphate, a supranational entity across the Muslim world. As a result, the organization strongly opposes nationalism and the basic concept of a nation-state. It blames the Afghan government for cooperating with the Western powers, which it alleges is pursuing a colonialist and capitalist agenda in the Islamic world. Although Hizbut-Tahrir does not call for an armed struggle, at times it does show a clear sympathy towards the Taliban and other militant organizations. On $10^{\text {th }}$ of March 2015, reacting to the reports of Taliban endorsement of peace negotiation with the Afghan government, Hizbut-Tahrir published an article on its official Facebook page, titled: "Peace Process in Afghanistan is a Political Suicide." The article claimed that "due to the fact that the Muslim Ummah does not have a legitimate state to represent its aspirations, any sort of peace negotiation with the belligerent and colonialist Kuffar (infidels), at both individual and organizational levels, in any occupied part of the Muslim land, is forbidden. Indeed this [peace negotiation] is a betrayal of the fundamentals of Sharia, therefore it is an act of political suicide." 36

The articulation of narratives of opposition to the Afghan government is not purely ideological. These groups combine their messages with practical references of people's frustrations with the corruption and ineffectiveness of the government institutions and periods of political crisis, such as the 2014 presidential elections. For example, on $3^{\text {rd }}$ April 2015, on the occasion of its $46^{\text {th }}$ anniversary, Hizb-e Islami published a message from its leader, Gulbuddin Hekmatyar, on its official Facebook page with reference to the 2014 election crisis:

"We witnessed the elections [were] being held with fraud and this indicates that occupiers are not able to create a and you still want the presence of these wild sustainable government. The democratic westerners'

\footnotetext{
${ }^{35}$ Aabed, Aya Hizb-e Islami ta Mansob Nor Dawlati Mamorin Ba Estefa Wokri? (Should the Members of Hizb-e Islami in Governmental Positions Resign?), Daily Shahadat, June 23, 2015, http://www.dailyshahadat.com/site/lekani_details/1106

${ }^{36}$ Saifullah Mustanir, The Peace Process in Afghanistan is a Political Suicide, The Khilafah, March 9, 2015, http://www.khilafah.com/the-peace-process-in-afghanistan-is-political-suicide, Afghanistan
} 
system cannot solve the problems of Afghans and it cannot lead to the welfare of people. I call upon all the mujahideen to unite and get organized better than before... the people of Afghanistan must be sure that Insha'Allah [God willing] all foreign troops will be expelled from our beloved country and in a free and independent Afghanistan, we will establish an Islamic government for the welfare of the people." ${ }^{37}$

While Jamiat-e Eslah is critical of the Afghan government, it supports some of its policies. For example, in April 2015, it praised its decision to back the Saudi Arabia-led war in Yemen. The organization focuses on bringing changes at the grassroots levels and supports the government initiatives to bring about socio-economic development. On 13 ${ }^{\text {th }}$ of July 2015, Jamiat-e Eslah posted an article on its official Facebook page, titled: "Why Shanghai Membership is Important for Afghanistan?" According to this article, "Russia and China, which enjoy decisive power in the Shanghai Cooperation Organization (SCO), are looking for alternative ways for maintaining stability in the region through Afghanistan. On the other hand, besides the security issues, SCO members are trying to work more on cultural and economic fields and this is important for Afghanistan ... using these opportunities created by the powerful and developed countries of the region, Afghanistan would enjoy the benefits of its geostrategic location through the New Silk Road and EuroAsia Union." ${ }^{38}$

In fighting corruption, Jamiat-e Eslah also emphasizes on the grassroots efforts and the responsibilities of citizens. On 20 th of March 2015, the organization posted an article on its official Facebook page, titled: "New Year, New Hopes. "The author claims that "we are all frustrated by the corruption surrounding us ... we all complain, but do we ever think of any solution to this problem? What is our role in dealing with all these? In order to eradicate corruption let's mobilize and start from ourselves." ${ }^{39}$

\subsubsection{Foreign intervention and the bilateral security agreement (BSA) with the US}

With regard to the presence of foreign troops in Afghanistan and Bilateral Security Agreement (BSA), most of the groups monitored during this research share more similar narrative, for example, the rejection of foreign intervention in Afghanistan. For the Taliban and Hizb-e Islami, withdrawal of all foreign troops from Afghanistan is one of the preconditions for making any peace deal with the Afghan government. Other Islamic activist groups, including Hizbut-Tahrir and Jamiat-e Eslah are also opposed to the presence of the foreign forces in Afghanistan. While arguing against the presence of foreign troops in Afghanistan and the BSA, these groups make practical references to real frustrations with the war efforts, mainly citing civilian casualties caused by the foreign troops or alleged desecration of Islamic values and symbols at the hands of foreign forces.

On $6^{\text {th }}$ of May 2015, the Taliban released a statement, on its official Facebook page, related to peace talks initiated by an NGO, Pugwash in Qatar. In the statement, the Taliban claims that "America and its

\footnotetext{
${ }^{37}$ Hizb-e Islami Afghanistan, Official Facebook Page, Accessed on April 3, 2015

${ }^{38}$ Ozwiat-e Daiemi Shanghai, Baraye Afghanistan Chera Mohim Ast? (Why Shanghai membership is important for Afghanistan?), Eslah Online, July 13, 2015, http://www.eslahonline.net/?p=59573

39 Eslah Online, Jamiat-e Eslah, Official Facebook Page, Accessed on March 20, 2015
} 
allies invaded a free and independent country by force. They have killed and arrested thousands [of Afghans], they have insulted our sacred religious values and they have ruined people's houses, gardens and land. In order to pave the way for peace and compromise among the Afghans, there must be an end to the occupation ... the continuation of occupation means the continuation of war." 40

Individual activists who are not directly linked to the militant organizations also hold such views. A similar argument is made by Abd-ul-Zahir Da'ae, a prominent Afghan religious scholar, through Payame Haq, a YouTube channel containing a number of religious lectures by various Afghan Ulama. In one of his speeches shared on the YouTube channel, he emphasizes that "the presence of foreign forces in Afghanistan is the cause for the continuation of war...once a reporter said that Afghanistan war is a war between America and the Taliban but I am saying no, you are deceived. This is a war between a Muslim nation and kuffar...this is a war against Muslim Ummah." ${ }^{41}$

Earlier, on 16th of March 2012, in a video clip posted on Eslah Online, the official YouTube channel belonging to Jamiat-e Eslah, Abd-ul-Salam Aabed, a prominent religious scholar and member of the organization explains his views on interaction with non-Muslims as follows:

\begin{abstract}
"Have faith and do not complain about your enemies that why they burnt the Quran? Why the enemy insulted me or why the enemy insulted Prophet Muhammad? You must understand that we cannot expect good from the enemy. ... Our enemies consider Islam as their adversary but unfortunately there are some Muslims or so called Muslims who try to make peace with them. They try to introduce our enemies as our friends and force us to have interaction with them. I want to make it clear that those who are not Muslims are our enemies and we should deal with them accordingly." ${ }^{42}$
\end{abstract}

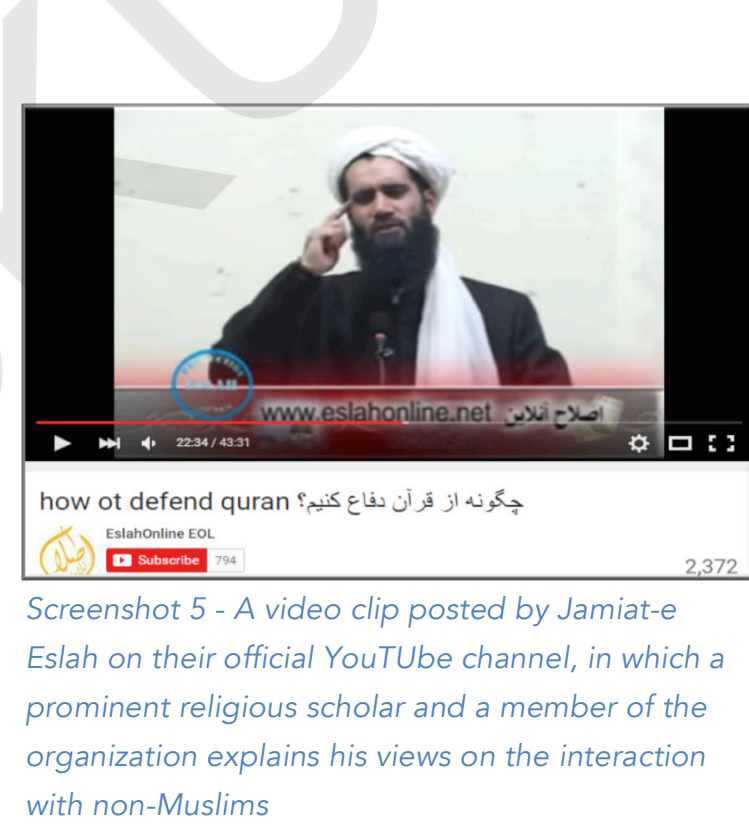

On $9^{\text {th }}$ of June 2015, Hizbut-Tahrir, reacting to the news of civilian casualties caused by US drone strikes in Khost province, posted an article on its official Facebook page, titled: "The Puppets and Their Masters are Playing with our Blood". The article claims that "on the first day of the year 2015, Obama

\footnotetext{
40 Alemara, Taliban Official Facebook Page, Accessed on May 6,2015

${ }^{41}$ Abduzahir Daee, Qowat-hayeKhariji Dar Afghanistan Bayad Nabashad(There Must Be No Foreign Forces in Afghanistan), Payam-e Haq, https://www.youtube.com/watch?v=3RVb1or9cPM , Accessed on December 17,2015

${ }^{42}$ Abdusalam Aabed, Chigona Az Quran Defa Konim? (How to Defend Quran?), Eslah Online, https://www.youtube.com/watch?v=YLKmqQevncg, Afghanistan, Accessed on March 16, 2015
} 
announced the end of military operation in Afghanistan but from that day until now, US drones are bombing, and every day they attack civilians, search their houses and arrest them." ${ }^{43}$

An important case in point are the controversies surrounding the green-on-blue attacks, in which members of the Afghan security forces attack their foreign mentors and advisors or their Afghan colleagues. The militant groups have clear reasons for encouraging such attacks. On $8^{\text {th }}$ of April 2015, Azim Khan, an Afghan soldier opened fire on American troops in Jalalabad, killing one US military officer and wounding several others before he was killed by one of his own colleagues. Soon after this incident, Hizb-e Islami claimed that Azim Khan was one of its members and celebrated him as a martyr. His photos were posted on the official Facebook page of Hizb-e Islami, with hundreds of Hizb-e Islami fans sharing those photos and hailing him as a hero. In one of the messages, which is an indicative of how these groups give heroic and personal recognition to such members, a follower of Hizb-e Islami wrote: "the biggest aspiration of martyr Azim Khan in his lifetime

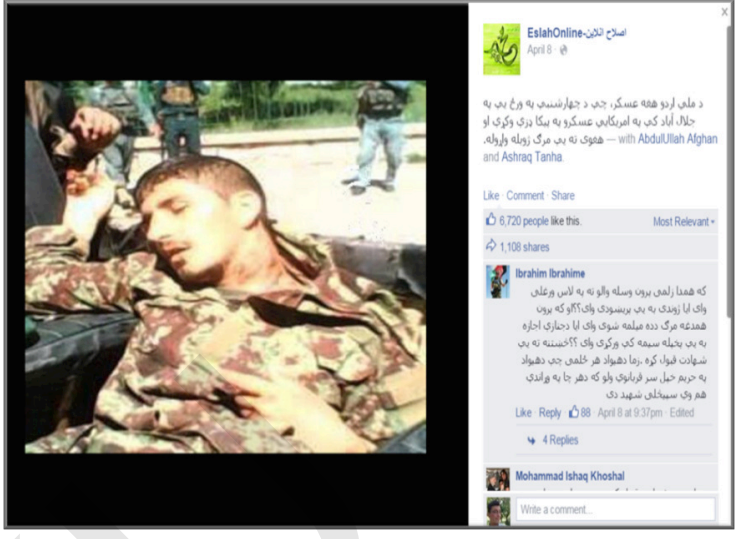

Screenshot 6 - Jamiat-e Eslah shared the news of the death of an Afghan soldier named Azim Khan, a green-on-blue attack convict showing some people praising his act in the comments' section of the post was to kill Americans and become a martyr himself.

He fulfilled his aim as he sent 8 American soldiers to hell and became a martyr himself." ${ }^{44}$ Pertinently, Jamiat-e Eslah also shared the news of the attack, but without taking any explicit position. However, hundreds of its followers posted a number of messages praising Azim Khan's action.

\subsubsection{Socio-cultural concerns}

Islamic groups, both peaceful activists and militant groups, share some common concerns about the social and cultural freedom of post-2001 Afghanistan. These concerns cover a wide range of issues, including the foreign cultural influences like musical programmes and events on the country's private television channels, and local traditional practices that are deemed un-Islamic, such as the celebration of Nowruz- the first day of spring or the Persian new year, during which the people from diverse ethnic communities mainly from the northern parts of Afghanistan come together to celebrate the day. The radical groups use social media platforms to promote a puritan interpretation of Islam and denounce the practices that are believed to contradict their interpretations of Islam.

For all the radical groups, the major concern is relatively liberal socio-political environment shaped in post-2001 Afghanistan. One such prominent concern is about the music and songs, particularly by

\footnotetext{
${ }^{43}$ The Puppets and Their Masters are Playing With Our Blood, The Khilafah, June 9, 2015http://www.khilafah.com/the-puppet-rulers-and-the-crusader-invaders-are-equally-playing-with-our-blood/ Afghanistan

${ }^{44}$ Hizb-e Islami Afghanistan, Official Facebook page, Accessed on April 8, 2015
} 
female singers, broadcasted on national radio and television channels. For example, on $21^{\text {st }}$ of March 2015, Jamiat-e Eslah published an article and shared it on its official Facebook page, titled: "The End of 1393 and the Beginning of 1394 with Nudity and Humiliation." The article claimed that "the communist institutions of yesterday and the democratic institutions of today are established under different names to misguide our youth from the path of humanity, Afghaniat and Islamiyat. They spend all their time and energy to promote corruption while we, Islamic parties, institutions and other big Islamic groups are busy with what is halal and what is haram? ... we must prevent every plot made by foreign or secular forces against this nation by conducting training programs for our people, especially for our youth ... We do not see the empowerment of our youth in [TV] programmes like "Afghan Star" [an annual reality singing competition organized by the private Tolo Television channel) and other worthless programmes in which young peoples' values are undermined." 45

Sometimes, such socio-cultural concerns are also expressed against some of the activities of civil society activists. For example, on $6^{\text {th }}$ of March 2015, a group of male activists attempted to attract public attention by appearing in a group wearing chadari in the center of Kabul. The idea was to mark a symbolic protest to highlight the lack of freedom for Afghan women and the complications of wearing hijab. The move elicited strong condemnation from most of the prominent Islamic groups, including the Taliban, Hizb-e Islami and Jamiat-e Eslah. What is striking is that in their opposition to perceived liberalization, these groups deploy the same terms that they use to demonize and delegitimize the Afghan government and foreign forces. For example, in reaction to this symbolic protest, Hizb-e Islami posted an article on its official Facebook page, titled: "Why Kuffar and

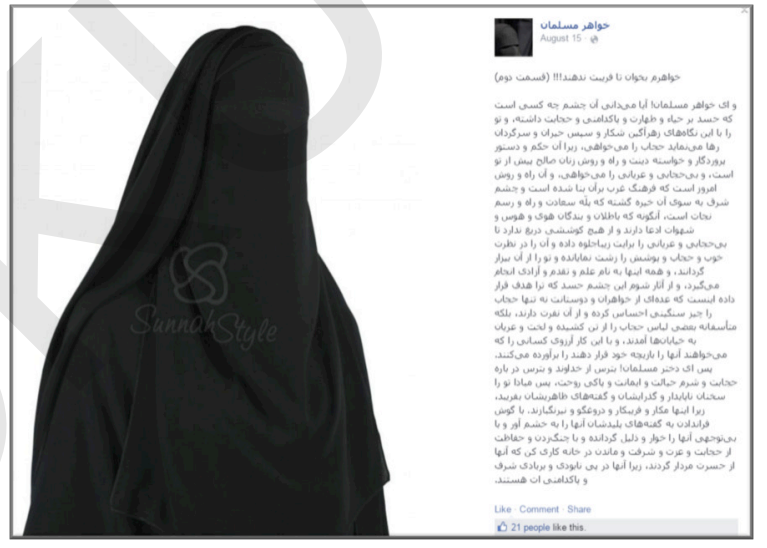

Screenshot 7 - A picture of a woman posted by a fake Facebook user, illustrating how Muslim women should dress Hypocrites Consider Chadari as Coercion"? Referring to the group of civil society activists, the article argued that "a satanic group insulted Islamic hijab as they claimed that chadari is being imposed on women, but in reality chadari is a perfect hijab for women as it includes every characteristic of hijab and is meant to safeguard the dignity and honor of women." ${ }^{46}$

Most Islamic activist groups are also concerned about the changes in gender relations, particularly the manner in which women appear in public. For example, on 30 $0^{\text {th }}$ of May 2015, Jamiat-e Eslah published an article on its official Facebook page warning women of men's satanic intentions. It emphasized that "the men who stare at women are like predators walking around a piece of meat." The article also offers women some specific advices: "If you (women) want to go outside you must ask for permission from your

\footnotetext{
${ }^{45}$ Eslah Online, Jamiat-e Eslah Official Facebook Page, Accessed on May 21, 2015

${ }^{46}$ Hizb-e Islami Afghanistan, Official Facebook Page, Accessed on March 6, 2015
} 
parents or husband; or one of your family members must accompany you as it is not allowed to be alone with an unknown man. It is necessary to wear hijab and you must not flirt with sellers [in shops] and should not engage with unknown men in markets or in the streets. ${ }^{47}$

However, the Islamic activist groups are also keen to emphasize the rights of women within the framework of Sharia law. In a press release posted on its official Facebook page on $6^{\text {th }}$ of May 2015, the Taliban emphasized that "concerning women, [the Islamic Emirate] is fully committed to respect all women's rights under the auspices of the sacred religion of Islam. In Islam, women have the right to choose whom to get married to, right to inheritance and have the right to study and work. The Islamic Emirate will respect these women's rights in a way that ensures their legitimate rights, human dignity and their Islamic status." Likewise, Hizbut-Tahrir promises an Islamic Khilafah in which the women can achieve all their rights according to Sharia law. In March 2015, the organization published an article on its official Facebook page, titled "Women Under the

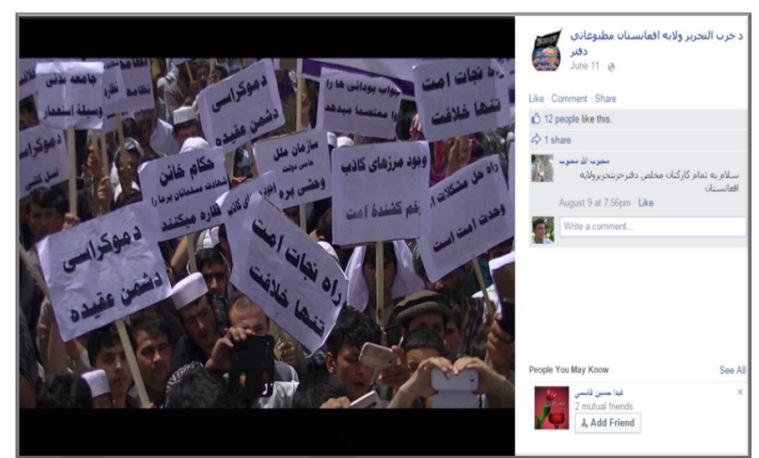

Screenshot 8 - A picture posted by Hizbut-Tahrir on its official Facebook page, showing a gathering of sympathizers condemning democracy and calling for the establishment of Islamic state

Ottoman Khilafah: "Challenging the Myths of Women and Their Economic Rights." The article argues that "the general picture derived from various records of the Ottoman Caliphate shows that the women were active in various economic fields, including the agricultural work and all kinds of handicraft works, such as: spinning, knitting and weaving. They would sell their products in the market places, manage other financial issues, lend money, enter into contracts, run businesses, organizations and foundations, be an employer or employee, and engage in various other economic activities." ${ }^{48}$

An important element of the ideology of Islamic activist groups on socio-cultural affairs is deeming the West responsible for what they regard as alien and corrupt cultural and social influences in Afghanistan. The responsibility for socio-cultural issues, such as: the violation of the women's rights, unemployment, and even increase in drug addiction among the population is often attributed to Western and secular values. For example in May 2015, a US-funded study found that the drug use in Afghanistan has grown up by 11 percent, with a total of three million drug users in Afghanistan. Hizbut-Tahrir published an article on its official Facebook page, titled: "Another Gift from Colonialism: Three Million People are Drug Addicts". Alluding to the rise in drug addiction among the young people in Afghanistan, the article argued that "the main problem is that the West and its puppet government got people busy with their

\footnotetext{
${ }^{47}$ Khaharam! Mowazib Bash, Bazar Kamingah-e Gorg-Hast (My Sister! Watch Out, Bazar is the Den of Wolves), Eslah Online, http://www.eslahonline.net/?p=42317, Afghanistan, April 7, 2013

${ }^{48}$ Women Under the Uthmani Khilafah: Challenging the Myths Women and Their Economic Rights, The Khilafah, March 8, 2015, http://www.khilafah.com/women-under-the-uthmani-khilafah-challenging-the-myths-women-andtheir-economic-rights-part-2/
} 
dollars and other Western concepts, such as profit making. [These are] the main criteria for measuring things ... As a result, your relationship with God is broken and it is natural to turn to drugs afterwards." ${ }^{49}$

Interestingly, some of the Islamic activist groups also reject the idea of civil society by calling it a Western concept. This is strange because many of the Islamic activist groups can also be considered part of the larger Afghan civil society and the fact is that they have significantly benefited from the social and political freedoms of the post-2001 Afghanistan. However, they often envisage civil society as constituted by Western-oriented secular activists and non-governmental organizations. They condemn civil society activists for their secular approach towards social problems. On $11^{\text {th }}$ of December 2014, a Taliban suicide bomber attacked a theatre play at Kabul's Istiqlal High School, which was staged to mark a protest against the suicide attacks. After the attack, the Taliban published a statement on its official Facebook page, stating: "The Islamic Emirate warns all those who work with the enemy's media platforms, all organizations operating under the name of civil society and disseminating propaganda against the mujahideen as well as the Islamic and national values, all those who stage demonstrations and participate in music and other corrupt activities, and especially those who try to misguide the youth, will not be safe from now on. Using any possible means [we] will attack them until such corrupt activities are wiped out of Afghanistan." 50

The argument about the meaning and the role of civil society became more significant during the debate that followed the lynching of Farkhuda. Civil society activists and some women's rights groups organized several demonstrations in Kabul, calling for the prosecution of all those involved in the lynching, with some activists challenging the authority and narratives of the religious establishment. Some women activists challenged the conservative mullahs by leading the funeral of Farkhunda themselves as against the usual tradition, by carrying her coffin from her home to the cemetery.

On $27^{\text {th }}$ of March 2015, "Paymanfilm Co", a YouTube channel mostly containing the religious speeches of Afghan Ulama, posted a video clip of a speech delivered by Dr. Abdullah Noor Ebad, a prominent religious scholar, on Farkhunda's murder. In the video clip, Dr. Ebad claims: "In my opinion, carrying Farkhonda's coffin by some [women] civil society activists is a serious insult to the disposed body of Farkhonda, which is far worse than the men beating her to death. Throughout the Islamic history, where do we see the women carrying a coffin?" ${ }^{51}$

The Islamic activist groups also condemn many traditional and local practices that they consider unIslamic. For example, in recent years, the celebration of the Afghan New Year, Nowruz, has stirred many

\footnotetext{
${ }^{49}$ Hadef, Tohfa-e Degar-e Esteamar: Se Million Nafar Motad Ba Mawad-e Mokhaderand (Another Gift from Colonialism: Three Millions of People are Drug Addicts), Hizbut-Tahrir, May 19, 2015, http://ht-

afghanistan.com/article.php?lang=dari\&parent $=42 \&$ category $=5 \&$ aid $=4000$

50 Mohammad Irfani, Aakheruzaman-e Farhang (Apocalypse of the Culture), Padidarha, http://padidarha.blogspot.com.es/2015/01/blog-post_97.html, Accessed on July 20, 2014

51 Abdullah Noor Ebad, Hadisa-e Shahadat-e Khahar Farkhonda Zeer-e Zarabin-e Islam Wa Moqif-e Ulama Dar Qebal-e Aan (The Martyrdom of Sister Farkhonda Under the Lens of Islam and the Position of Ulama Toward It), Paymanfilm Co, https, www.youtube.com/watch?v=Jtkv"ykpTknA, Accessed on March 27, 2015
} 
heated debates among the radical Islamic activist groups and more liberal or secular groups. On $20^{\text {th }}$ of March 2015, Hizb-e Islami posted a video clip in which one of its members, Abu Obaidullah Mutawakil argues that: "people gather to celebrate Nowruz and there are some Mullahs who approve it. These so called Muslims claim that they love Islam and the prophet Muhammad, but they are liars and Prophet Muhammad would be cursing them for their activities." ${ }^{52}$

\subsubsection{Strategies for social and political action and views on jihad and mujahideen}

Both the Taliban and the Hizb-e Islami have their roots in the resistance movement against the Soviet occupation of Afghanistan in the 1980s. Interestingly, Hizbut-Tahrir makes the same references to jihad against Soviet Union, despite the fact that the organization had no presence or involvement at that time. However, while recognizing the overall legacy of the jihad against the Soviet occupation, the organization condemns former mujahideen leaders and groups that have chosen to work with the government of Afghanistan post-2001. Jamiat-e Eslah also praises the jihad against the Soviet occupation of the country in the 1980s but distances itself from the mujahideen organizations that participated in the civil war of the 1990s. The main point is that while highlighting their links to the Afghan jihad against the Soviet occupation in the 1980s, Jamiat-e Eslah portrays itself as the defender of the nation or the Muslim Ummah, but questions the legitimacy of the former mujahideen who participated in the post-2001 political system.

For example, on $14^{\text {th }}$ and $15^{\text {th }}$ of March 2015, on the anniversary of the March 1979 Herat uprising against the then communist regime of Kabul, Jamiat-e Eslah published several articles celebrating the uprising as well as the jihad. One of the published articles, titled: "A New Look at the 24 Hut Revolution of the Muslim People of Herat,"

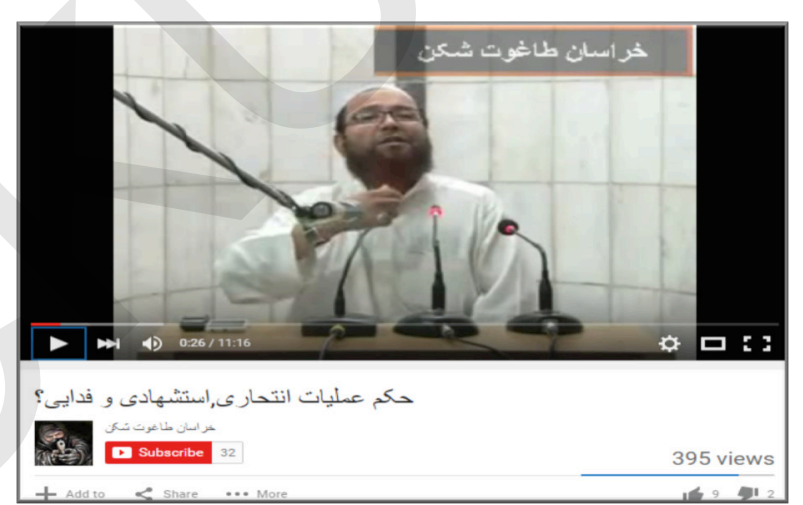

Screenshot 9 - Abu Obaidullah Mutawakil, a wellknown religious scholar justifying suicide attacks in a video clip published by Khorasan Taghot Shekan, a YouTube channel run by a Taliban sympathizer argues that the main aim of the Herat uprising was to defend Islamic values and beliefs of the Afghan people. The author expressed his concerns while stating that those respected values and beliefs are once again being threatened. He further said, "Today, there are things that hurt the spirit of the martyrs; our nation is polarized in the name of ethnicity, language and factions, whereas back then people had learnt the practical lessons of solidarity. Today, we are under the hegemony of foreigners and their cultural oppression; while they [Mujahideenn] scarified their lives for the preservation of our independence, freedom and protection of our religious culture. Not only are the killers of our people not punished, but also some of them are a part of the Afghan government. Profitable banks, corrupt media,

\footnotetext{
52 Abu Obaidullah Mutawakil, Nawroz Wa Mullahai Shekamparast (Nawroz and Glutton Mullahs), Rashed Muslim, March 16, 2015, https://www.youtube.com/watch?v=iOyl5FGJKaA
} 
unveiling of women, chaos and homicide are damaging our society, while they [martyrs] sacrificed themselves to protect us from these dangers and problems." ${ }^{53}$

For the Taliban and the armed wing of Hizb-e Islami, the commemoration of the history of jihad has more immediate reasons. They believe that jihad is an ongoing affair, and justify and encourage any sort of armed and violent actions against the Afghan government and its Western allies, including suicide bombings, direct armed offensives, secret assassinations and green on blue attacks. Out of these, the suicide attacks are the most extreme form of radicalization, representing the zenith of the radicalization pyramid. Militant groups use words such as "martyrdom operations" (amaliat-e esteshhadi), "justified executions," and green on blue attacks as "heroic actions, "in order to describe and justify such attacks. This view is also shared by some well-known radical Ulama who are not directly affiliated with the militant groups. For example, Abu Obaidullah Mutawakil, a well-known religious scholar in Afghanistan justified suicide attacks in a video clip posted on "Khorasan Taghot Shekan," a YouTube channel. Abu Obaidullah says, "In Islam suicide is haram but "martyrdom operation" is different ... today there is no way to crush down the enemy who is equipped with sophisticated weapons and technology but through suicide attacks. Today if the kuffar are defeated, it is because of these kinds of attacks. Those Ulama who denounce martyrdom operations will go to hell." ${ }^{54}$ The video also rejected the claims that suicide attackers are the individuals who have lost interest in life. The insurgents also refute claims that civilians are killed in such attacks. To dismiss the reports highlighting the impact of suicide bombings on civilian population, Hizb-e Islami posted a statement on $16^{\text {th }}$ of April 2015 on its official Facebook page, in which Gulbuddin Hekmatyar stated, "Those with the military experiences know that the roadside bombings and martyrdom operations do not cause civilian casualties as the mujahideen take utmost care while carrying out such attacks." 55

Consequently, direct assassinations of the government officials and rival forces are carried out and encouraged by the Taliban and Hizbe- Islami as "justified execution" as per the Sharia law. For example, on $17^{\text {th }}$ of July 2015, the Taliban posted a message on its official Facebook page announcing the news of the killing of a Police Chief in Dehrawood district of Urozgan province. In this statement, it was stated that, "Haji Talib served for 3 years as the head of security for the enemy and during that time he oppressed the people, tortured and killed many of our beloved countrymen. Alhamdu-lillah (Thanks to God) today he met with his deserving fate." ${ }^{16}$

In contrast to the militant groups, Hizbut-Tahrir applauds the jihad against the Soviet occupation in the 1980s, but the organization is critical of the role of the former mujahideen in the post-2001 political system. For example, on $1^{\text {st }}$ of July 2015, Hizbut-Tahrir reacted to the US-led NATO's operation on a weapons' store of a former mujahideen commander in the Parwan province. The operation evoked

\footnotetext{
53 Eslah Online, Jamiat-e Eslah Official Facebook Page, Accessed on March 15, 2015

${ }^{54}$ Abu Obaidullah Mutawakil, Hokme Amaliate Entehari, Esteshhadi, Fedaee? (Sentence for Suicide and Martyrdom Operation), Khorasan Taghot Shekan, https://www.youtube.com/watch?v=sT6xNrHpq-4, Accessed on September 16,2015

${ }^{55}$ Hizb-e Islami Afghanistan, Official Facebook Page, Accessed on April 16, 2015

${ }^{56}$ Alemarah, Taliban Official Facebook Page, Accessed on July 17, 2015
} 
strong reactions from the leaders of the Jamiat-e Islami, including Abdullah Abdullah, the Chief Executive Officer (CEO) of the National Unity Government (NUG). A commentary posted on the official Facebook page of Hizbut-Tahrir, condemned foreign forces for carrying out the attack and the CEO of Afghanistan for his selective reaction to the situation of the mujahideen. "We strongly condemn the airstrike of the colonialist invaders and the statement of Abdullah Abdullah ... it is indeed a shame and disgust ... that the oppressed Muslims of Afghanistan, including women, children, elderly, and the mujahideen fighting against the invaders are killed and tortured in many parts of Afghanistan. Neither Abdullah Abdullah nor any other government official raises their voice against the invaders. However, when such incidents happen to their own supporters, they start making shallow and futile statements asking the invaders' military commander to provide clarifications about the incident. This one-sided attitude of Abdullah Abdullah and other Afghan government officials show their prejudice, which is based on the tribal, linguistic and political affiliations. This also reveals to the Muslim and mujahid nation of Afghanistan that these rulers are moved only when their own personal and political interests are jeopardized. We all know that he is one of the so-called jihadists who abandoned jihad and signed a deal with the US and NATO forces. By doing this, he betrayed the blood of martyrs, the orphans and widows of the war against Soviet Union who sacrificed their lives and property for the nation." 57

While the Islamic groups studied in this research paper share important ideological worldviews, they also compete with one another in attracting financial and military resources and in gaining social support among the ordinary people. As explained by McCauley and Moskalenko, ${ }^{58}$ the competition between groups formed around the shared common causes can intensify radicalization processes by encouraging them to outshine one another in appealing to the similar social support bases.

Despite the significant differences in identification of problems and strategies for action, the Islamic activist groups in Afghanistan share important ideological narratives. The significance of these shared ideological narratives became apparent with the announcement of the death of Mullah Muhammad Omar, the leader of the Taliban at the end of July 2015. Jamiat-e Eslah posted several condolence messages regarding the death of Mullah Omar on its official Facebook page.

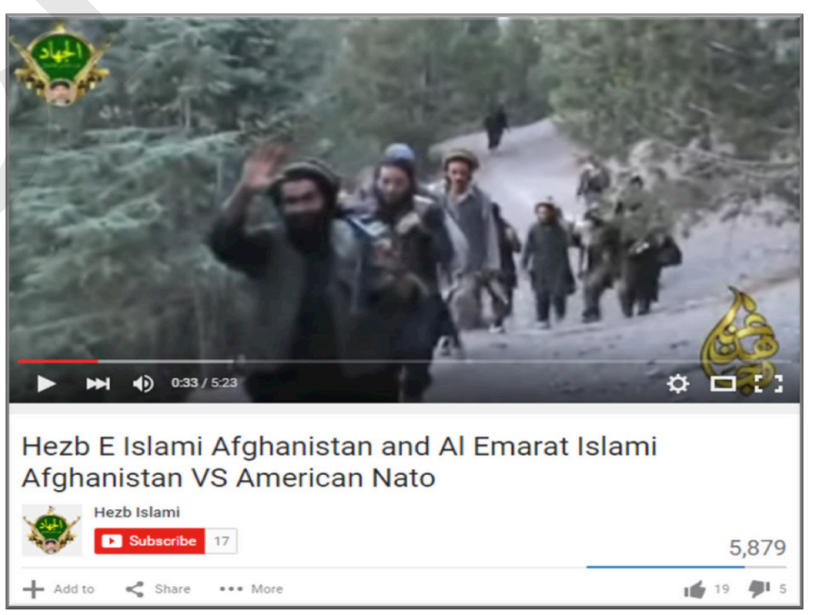

Screenshot 10 - A video posted by Hizb-e Islami on their official You Tube channel, showing the alliance between Taliban ad Hizb-e Islami against the US-led NATO forces in Afghanistan Similarly, Hizb-e Islami posted a condolence

\footnotetext{
57 We Strongly Condemn the Airstrike of the Colonialist Invaders and the Statement of Abdullah, Hizbut-Tahrir, http://ht-afghanistan.com/article.php?lang=english\&parent=43\&category=13\&aid=4315,Afghanistan, June 30, 2015 ${ }^{58}$ Clark McCauley \& Sophia Moskalenko, 'Mechanisms of Political Radicalization: Pathways towards Terrorism', Taylor Francis Online, 2008, http://www.tandfonline.com/doi/abs/10.1080/09546550802073367
} 
message on its official Facebook page, in which Gulbuddin Hekmatyar said, "The Afghan nation and the Islamic Ummah has lost an honorable mujahid leader at a time of need ... The mujahideen must struggle for the freedom of their country and without setting any preconditions for the withdrawal of occupational forces. We must believe in unity of Muslims. As the Islamic Ummah is at war against the crusaders, the mujahideen must support each others' efforts. In confrontation with the US occupiers, they must do what they did against the Russian occupiers. ... the independence of Afghanistan was Mullah Muhammad Omar Mujahid's wish and with the help of God we must make it a reality." 59

On $18^{\text {th }}$ of July 2015 , Hizb-e Islami published an open letter written by Habibullah Hekmatyar, one of the sons of Gulbuddin Hekmatyar, which was addressed to Mullah Omar. In 2015, Habibullah Hekmatyar's official Facebook page became an important platform to disseminate Hizb-e Islami's radical narratives. ${ }^{60}$ In the letter, Habibullah criticized Mullah Omar for trying to isolate other jihadi groups. His letter notes, "Most of the mujahedin started and encouraged jihad to follow their religious teachings but the question is whether your group is the only legitimate group to conduct jihad? Those who have some disagreements with the Islamic Emirate do not have the right for jihad? ... you claim that thousands of Ulama pledged Bay'ah (allegiance) to you but [you must know] that while electing the leader of Hizb-e Islami, one million Afghan Mujahideen participated, including hundreds and thousands of Ulama. Nowadays, in Pakistan there is a camp in which more than one thousand of Ulama are supporting Hizbelslami's Amir. So why do you oppose Hizb-e Islami? While you claim this right for yourself [the leadership of Islamic Emirate] then why do you fight against Abu Bakr al-Baghdadi who claims to be the caliph? Why do you fight against them? Does jihad succeed in this way or through cooperation and brotherhood among the mujahideen? ... I would like you to make compromises with the Afghan jihadist groups, and make a unified and rational platform for mutual understanding."61

However, despite the ideological similarities, inter-group competition among the militant groups became more intense after the emergence of the Daesh forces in the south-eastern parts of Afghanistan. Among the main Afghan militant groups, only Hizb-e Islami announced its support for the Daesh affiliates in Afghanistan. On $13^{\text {th }}$ of July 2015, Hizb-e Islami posted an article in support of Daesh on its official Facebook page. The article asked its followers, "In your view what kind of position Hizb-e Islami should take? Everybody knows that the Taliban backed by Iran has announced a war against the Daesh mujahideen. ... Everybody knows that the Daesh are fighting against the crusaders. ... If these mujahideen get killed by the joint operations of the Taliban and Americans, the US will not have any problem with the Taliban anymore. Now what do you think? Does Hizb-e Islami, well-known for its chivalry, need to help its Daesh mujahid brothers or not? ... There are some Afghans who think that Daesh mujahideen would do the same inhuman activities in Afghanistan as they did in Iraq, but [they must know that] incidents in Iraq took place in reaction to the numerous shameless crimes committed by the Iranian mercenaries in Iraq. The Daesh affiliates in Afghanistan diverged [from the Taliban] because of its dependence on a neighboring intelligence agency. Daesh also lost confidence in Taliban due to

\footnotetext{
${ }^{59}$ Hizb-e Islami Afghanistan, Official Facebook Page, Accessed on August 2, 2015

60 Habibur Rahman Hekmatyar, Facebook Page, Accessed on July 18, 2015

${ }^{61}$ Hizb-e Islami Afghanistan, Official Facebook Page, Accessed on July 18,2015
} 
the death of Mullah Omar and there are fears that the Taliban's commitment to jihad may be jeopardized due to their power sharing deals with America." ${ }^{22}$

The presence of the group is the most threatening to the Taliban, which proclaims to be the main movement of the mujahideen in Afghanistan. In June 2015, the Taliban published a letter on its official Facebook page, which was addressed to Abu Bakr al-Baghdadi, warning him against waging a separate jihad in Afghanistan. ${ }^{63}$ The Taliban's opposition to the presence of Daesh in Afghanistan is motivated by concerns that some of its own disgruntled factions might be attracted to more radical and violent tactics employed by Daesh. The brutal tactics of Daesh were considered too extreme to be justified by other Islamic groups. Jamiat-e Eslah posted comments on its official Facebook page condemning Daesh's brutality. A more clearly articulated opposition came from Hizbut-Tahrir. The opposition of Hizbut-Tahrir to the Daesh is significant because the later proclaims to have already established a caliphate under Abu Bakr al-Baghdadi, an idea which has been central to the eventual goal of the former for several decades. Hizbut-Tahrir condemns Daesh as a US-backed plot. On 13 ${ }^{\text {th }}$ of March 2015, Hizbut-Tahrir published an article on its official Facebook page titled: "The New Chapter of War in Afghanistan. "The article stated, "America is maintaining its long term colonial presence in Afghanistan under a new scenario, [by] creating a terrorized and dangerous environment for the people. The presence of Daesh in Afghanistan could be categorized under such a scenario because the Daesh threat and America's long-term presence would only intensify the war and hatred among the people of Afghanistan. Consequently, there is a new killing agenda going on in the name of Daesh and fighting against the Daesh would result into another phase of bloodshed in Afghanistan. With some minor differences, the Americans want to create a similar chaos in Afghanistan as in Iraq, in order to stage another chapter of genocide and mass killings." ${ }^{64}$

\subsubsection{Islamic Ummah affairs}

Transnational Islamic solidarity is an important element of Islamic activist and militant groups. These groups define their identity as part of the broader Muslim Ummah and as a result react to and discuss the political and socio-cultural developments across the Muslim world. Two aspects of their social media commentaries about the Muslim Ummah affairs are worth mentioning: i) an expression of solidarity and sympathy with the Muslim countries that are perceived to suffering at the hands of Western powers;

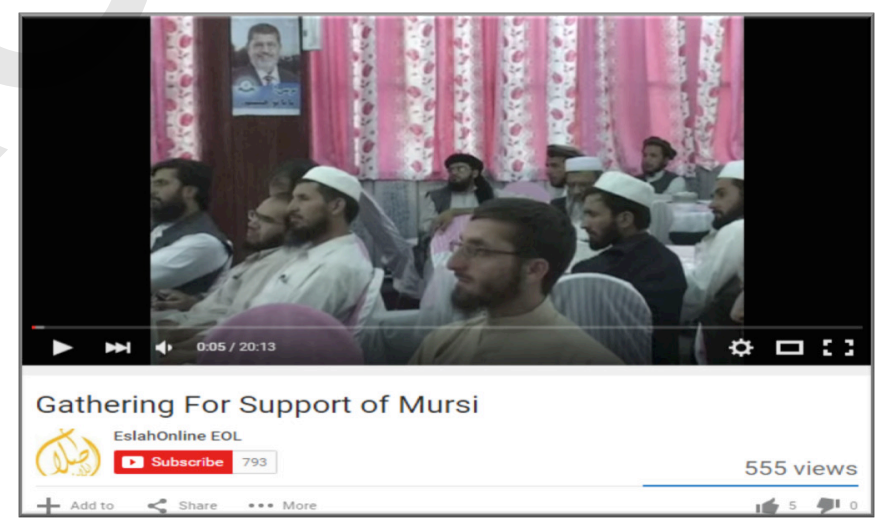

Screenshot 11 - A video posted by Jamiat-e Eslah on their official You Tube channel showing the gathering of sympathizers of Mohammad Mursi, the ousted Egyptian president of Muslim Brotherhood

\footnotetext{
62 Hizb-e Islami Afghanistan, Official Facebook Page, Accessed on July 13, 2015

${ }^{63}$ Alemarah, Taliban Official Facebook Page, Accessed on Jun 15, 2015

${ }^{64}$ Da Hizbut-Tahrir Wilayah Afghanistan Matbuati Daftar, Hizbut-Tahrir's Official Facebook Page, Accessed on March 13, 2015
} 
and ii) criticism of governments and political leaders of Muslim countries that are considered as corrupt, oppressive and subservient to Western powers. For example, when the Muslim Brotherhood leaders in Egypt were sentenced to death in May 2015, Hizb-e Islami and Jamiat-e Eslah posted condemnation messages on their official Facebook pages and announced their full support for the Muslim Brotherhood. On $21^{\text {st }}$ of May 2015, Jamiat-e Eslah published an article written by Nasir Ahmad Nawidi, the Chairperson of the Jamiat-e Eslah's central committee. In the article, titled: "Rescue Justice," the author argued, "Looking into the political stance of Americans and the most European governments, one can see that there is nothing but endorsements of the shameful decision of Egyptian courts and giving more time to the military regime of Egypt in order to oppress freedom and democracy. ... So all those who believe in freedom and justice regardless of race, religion and gender must defend Mohammad Mursi and his followers ... if not then they are to be condemned in this lifetime as well as in the life hereafter before God and the next generations will not forgive them." ${ }^{65}$

The bond of Islamic solidarity sometimes overrides competition and rivalry among these groups. Even Taliban, with its strong opposition to the expansion of Daesh in Afghanistan, did not hesitate to express sympathy with Daesh in its role in the Middle East. The Taliban's open letter to Daesh began with commending what it described as Daesh's jihad against the US occupiers. The letter addressed to Abu Bakr al-Baghdadi, begins with these remarks: "We pray to God that may all the Mujahideen succeed in their path to implement Islamic Sharia." 66

The concept of Muslim Ummah plays a central role for the militant and other Islamic activist groups in Afghanistan. On $21^{\text {st }}$ of July 2015, on the occasion of Eid Al-Fitr (Islamic holiday which marks the end of the fasting month of the Islamic calendar - Ramadan), both Hizbut-Tahrir and Jamiat-e Eslah posted messages on their official Facebook pages. The commemoration of the occasion was combined with the expressions of solidarity and sympathy with Muslims suffering from what they call plots against Muslim Ummah. In its message Hizbut-Tahrir argued: "While celebrating Eid-ul Fitr, it is important to reflect on various calamities the Muslim world is faced with. The killings taking place in Syria, Iraq and Yemen are a series of multiple injustices perpetrated by the West and its agents against the Islamic Ummah." ${ }^{67}$ On $16^{\text {th }}$ of July 2015, Jamiat-e Eslah combined its assessment of the situation in Afghanistan with the Muslim countries undergoing conflict. The article stated, "Unfortunately as Eid approaches, the rate of poverty and depression are higher than before and our youth continues to suffer from unemployment. Afghanistan is facing new political and military challenges, as people do not enjoy stability. The NUG and its supporters disappointed people and the prospects of peace in future are unclear. Meanwhile many Islamic brother nations are suffering; the coup d'etat regime of Egypt is killing innocent people who are struggling to maintain their freedom and dignity. International plot for the continuation of crisis and gradual demolition of Syria is going on. The Jewish conspiracy against the first Qibla of Muslims (Jerusalem) is continuing ... Muslims of Myanmar are still being killed by extremist Buddhists ... this year once again the Government of China prevented Muslims of Xinjiang from fasting. On the other hand

${ }^{65}$ Eslah Online, Jamiat-e Eslah Official Facebook Page, Accessed on May 21, 2015

${ }^{66}$ Alemarah, Taliban Official Facebook Page, Accessed on June 16, 2015

${ }^{67}$ Da Hizbut-Tahrir Wilayah Afghanistan Matbuati Daftar, Hizbut-Tahrir's Official Facebook Page, Accessed on July 21,2015 
there are new plots being planned against Libya and Tunisia, and the enemies of Islam from within and outside of Islamic societies are pressuring Islamic movements and sons of Ummah from Morocco to Indonesia, in order to isolate them and misuse their wealth." 68

The expression of transnational Islamic solidarity by these groups is that the problems across the Muslim world are generalized and related to one another as part of the broader conspiracy. The responsibility for the sufferings of Muslims is attributed to the non-Muslim Western powers or national governments. The Western powers and national governments are demonized as kuffar or stooges of imperialists' powers, against which they stand as one force that can represent and defend the interests of the Ummah and offer solutions to the current problems.

\subsection{The role of Taliban hymns and songs in the radicalization processes in Afghanistan}

Radical ideas are also spread through the use of religiously inspired songs by the Taliban, commonly referred to as Taliban hymns. These songs are disseminated via Bluetooth devices by individuals living predominantly in rural areas of Afghanistan and as a result offer important avenues for understanding the discursive aspects of Taliban insurgency and social mobilization strategies. Similar to social media platforms in urban areas, these hymns communicate Taliban's messages to social groups that have limited access to internet. As a result of a lack of access, low-cost/low data alternative to social media are specifically prevalent in rural geographies. However, this study found that hymns are also increasingly being circulated via different social media platforms, such as Facebook and Youtube. Prior to this research, there has not been any considerable research conducted on the use of Taliban hymns. However, this study concludes that these hymns are anecdotally relevant to concerns of radicalization.

Taliban hymns are songs with religious content, but without music. Most of these songs call on Afghan youth to fight against the government and international forces, claiming that the fight against the regime and its backers is an obligation of each individual. In fact, the Taliban increasingly use these hymns to encourage youth to take up arms and using their emotions to encourage them to go to the front lines. Often, these hymns are in Pashto and use simple language construction, making them accessible even to individuals with low literacy levels. These include many members of the Afghan National Security Forces (ANSF). ${ }^{69}$ As a result, these hymns are incredibly effective at being accessed by nearly all Afghan educational demographics.

While there are a number of known Taliban hymns, this study analyses 11 such hymns disseminating radical ideologies in the following areas: 1) preaching people to embrace religion, 2) promoting messages of war against the government, 3) recruiting more youth, 4) infiltrating the security forces, 5) increasing their visibility among the people and the international community, and 6) remembering and glorifying their dead members.

\footnotetext{
${ }^{68}$ Eslah Online, Jamiat-e Eslah Official Facebook Page, Accessed on July 16, 2015

${ }^{69}$ Bilal Sarwari, Anatomy of an Afghan 'Turncoat' Killer, BBC, October 21, 2011, http://www.bbc.com/news/magazine-14713523
} 
While the content of these hymns is readily accessible, the hymns are accessible for purchase in many areas for little money. Often, these messages are produced in the bazaars of Peshawar city and sold initially in those music markets. ${ }^{70}$ Moreover, these hymns are posted online on different websites, including YouTube, Taliban's official website and other social media platforms, such as Facebook. These hymns are transported secretly to Afghanistan in the form of cassettes and memory cards. These hymns are also available in shops selling mobile phones, computers and music and can be uploaded in return of paying less than two US Dollars in these shops. ${ }^{71}$

\subsubsection{Preaching people to embrace religion}

The Taliban is a right-wing religious organization and affirms that music is prohibited in Islam. Therefore, during their reign, the Taliban censored music and restricted artistic activities, considering such innovations as distractions from the practice of authentic Islam and true worship. During the Taliban's rule, music shops were not allowed to sell any kind of music except for Taliban hymns and other religious songs. The Taliban have argued that music is prohibited in Islam because it weakens ones belief and results in forgetting God. The Taliban regards its own hymns as an alternative to music and during their rule they even tried to replace popular songs with the hymns sung by Mawlai Faqir Mohammad and Qari Sarajuddin, among others. During their rule, the Taliban would regularly use hymns in official meetings, celebration of national days, and military exercises and parades.

These hymns call people to Islam and emphasize the significance of Islamic jurisprudence and beliefs. There is also focus on the qualities of God and the Prophet Muhammad, and signs of Jannah (paradise). There is also reference to the pilgrimage in Mecca and other religious affairs. These hymns are locally referred to as 'naat-e sharif'. For instance, the following hymn delineates the qualities of the Prophet Muhammad:

Muhammad is a true representation of justice

Muhammad, you are a comfort to the heart of a lover

With your arrival, the light of justice was spread

Darkness has gone; you are a light and reflection

You are a comfort to the heart of a lover

In this hymn, the Taliban are trying to highlight the activities of Prophet Muhammad by calling him a true representation of justice and urge people to follow in his footsteps. Songs with religious messages, especially praising Prophet Muhammad, are popular among Muslims in other countries as well. However, the Taliban uses these hymns to generate and gain sympathy for their cause. These songs are emotionally very attractive to devout Muslims and once they start listening to the religious songs, they come across songs that not only talk about religion and Prophet Muhammad but also about jihad for the sake of Islam. The Taliban uses these songs as a tactic to influence young generations in Afghanistan so as to recruit them.

\footnotetext{
${ }^{70}$ Interview with an Afghan Journalist, September 2015

71 lbid.
} 


\subsubsection{Promoting messages of war against the government}

In recent years, the Taliban has increased the use of these hymns to launch a scathing attack on the government. In these hymns, the Taliban makes references to corruption, weak governance, maladministration practices and calling the Afghan government officials puppets of Western countries. They have also written hymns targeting well-known individuals and used them as tools to positively influence their target audience. For instance, in the following hymn, the Taliban have called on the former President - Hamid Karzai to expel foreigners:

Hey Karzai, you should expel the British from this country

They may be your guests, but expel my enemies

Hey Karzai, say you need neither their rangers nor their planes

I am a pure Muslim, and I want neither their dollars nor their assistance, tell this to Karzai

In this hymn, the Taliban argues that foreigners have invaded Afghanistan and have done so as guests of President Karzai, aiming to arouse passion among Afghans against the government and foreigners.

The Taliban released another hymn on the subject of US dollars. Yet again, the Taliban made reference to corruption and claimed that the money has deviated the so-called people's leaders. The lyrics are as follows:

You have deviated many people

You dollar - you are a magician and have a lot of attraction

The one who was our leader yesterday, that person was also our preacher

Today, he is your slave, oh the magician of dollar, you have a lot of attraction

This hymn conveys the message that many people acquired their wealth illegally in the last 15 years, through a government that has been setup by the foreigners. The Taliban also wanted to send a message to the people who became rich after 2001, calling it another sign of the American involvement in the internal affairs of Afghanistan, which lead a majority of the Afghan people to corrupt practices.

\subsubsection{Conscription of the youth}

There is a substantial anecdotal evidence that young people in both rural areas as well as in major cities of Afghanistan are inspired by these hymns and actively share them via Bluetooth and other social media platforms. A report by Azadi radio, a news agency broadcasting news in 23 countries, for example, interviewed several young men in Kabul for their use of Taliban hymns, all of the respondents suggested that these hymns inspired them to fight. There has been substantial evidence that people in major cities, including Kabul, listen to these hymns. One young man told Azadi Radio that he enjoys listening to these hymns and it helps him understand better why he should join the Taliban. Another youngster interviewed by the Azadi radio claimed that listening to these songs and hymns motivates him to be part 
of jihad. According to this report, a considerable number of youth in Afghanistan have these hymns in their mobile phones and share them easily with others via Bluetooth. ${ }^{72}$

A considerable focus of the Taliban hymns and songs is to attract new recruits. Since the Taliban hymns are now easily available on internet, they have the potential to influence the young people who have easy access to the internet, in addition to the young people who gain access to these hymns by receiving them via Bluetooth in the areas where internet is not accessible. The Taliban also uses these hymns and religious songs in the background of some of their videos as part of their recruitment strategy. Ordinary people watch the Taliban propaganda videos and listen to their hymns on their mobile phones. For example, in the following hymn, the Taliban addresses young men, arguing that 'sitting at home is what women do' and it is 'men that go to the fighting arena:'

Go put bangles on, like women do Pick a pot like women do and bring water If you are not going to fight, what is the use of your long hair?

All you do is eat - and that is all

And those who do not take part in the war, should be shot in their heads

Those who do not take part in war, sleep in palang (shade)

Karzai puts on different colors all day long

He dines and wines (eats and drinks) and sleeps

And those who do not go to the battlefield

Another hymn which is used for recruiting young people:

To have service shoes and have put on a green rocket on my shoulder

I wish I were not a single lady, I wish I were not a single lady

I wish I were not a single lady, and have fought against Jews in the mountains

I wish I were not a single lady, and had my life full of struggles

I wish I were not a single lady, and I would pull the trigger using your bullets

In an interview to Azadi Radio, Mohammad Ismail Yoon, the owner of the Zhwandoon media and the head of the National Movement, said that these hymns could also generate anger and resentment among the youth against the government and foreign forces. These songs arouse their sentiments and create sympathy for the Taliban. According to Mr. Yoon, listening to these songs is like 'playing music to the snake' and it can have an immense effect on the people and the results would not be in favor of Afghanistan. He further stated that there is consensus now that the Taliban uses the hymns as an effective tool to promote their agendas. It is an obvious fact now that the Taliban cannot use radio or TV for their campaigning, therefore the production of cassettes containing these songs provide them with an alternative to reach to the larger population.

\footnotetext{
72 Sami Basri, Chera Shenidan-e Tarana HayeTaliban Dar Mian-e Jawanan-e Afghan Bishtar Shoda Ast? (Why Taliban Songs Got More Popular Among Youth?), Azadi Radio, July 10, 2011, http://da.azadiradio.org/content/article/24261145.html
} 
The Taliban uses these hymns as an effective tool to mobilize communities and meet them. In an interview $^{73}$ with a resident from Chahardar district in Helmand province, it was revealed that the Taliban visit the local mosques from time to time and play the hymns using the loud speakers of the mosques. He further added that initially he was not interested in listening to these hymns. However, after being insisted by some Taliban members, he started to listen to these songs and gradually his interest grew and he began to think that he should serve God by fighting against the infidels. This shows the impact of these hymns and the influence it has on people who regularly listen them. There are several factors why people get influenced by these hymns. The content of these hymns is very appealing for Muslims living in Afghanistan. For example, the hymn mentioned above states that the former president of Afghanistan, Hamid Karzai is not following the basic teachings of Islam. In the hymn Taliban claims that Karzai is busy with the luxuries of life as he sleeps and drinks. It is noteworthy to mention here that alcohol in any form is strictly forbidden in Islam and the Taliban highlights such things about the high government officials to increase people's resentment against them and to favor their own cause.

\subsubsection{Infiltration of the security forces}

Anecdotal evidences suggest that the Taliban hymns are popular even amongst the security forces, largely because of the low levels of literacy among the recruits. Most of the security sector staff in Afghanistan either have low levels of education or no formal education ${ }^{74}$. According to the Tolo news, nearly $70 \%$ of the staff working for the Ministry of Interior (Mol) are illiterate. ${ }^{75}$ Taliban songs are written in simple language and their message is very clear to the audience. The Afghan National Security Forces (ANSF) have easy access to these hymns like the rest of the population in Afghanistan. These hymns have been directly cited as a cause of at least one green-on-blue attack that took place in November 2010. In this attack, ${ }^{76}$ Ezatullah Wazirwal, a border policeman, who was receiving training from the Americans, attacked a number of his trainers who were taking rest at that moment. Ezatullah killed 6 American soldiers and was later killed by other security forces. A subsequent BBC investigation ${ }^{77}$ revealed that Ezatullah carried out the attack after having been influenced by the Taliban. One of his close friends revealed to the BBC that Ezatullah would listen to the Taliban hymns. The same was confirmed after investigation by the ANSFs as Taliban hymns, which encouraged such attacks, were retrieved from his mobile phone. The following two hymns were retrieved from Ezatullah's mobile phone:

\footnotetext{
73 Interview with an Afghan Journalist, September 15, 2015

74 Farid Hussain khail, 60,000 Afghan Police Are Illiterate, Tolo News, April 22, 2015, http://www.tolonews.com/en/afghanistan/19181-60000-afghan-police-are-illiterate, Afghanistan 75 Ibid.

76 Bilal Sarwari, Anatomy of an Afghan 'Turncoat' Killer, BBC, October 21, 2011, http://www.bbc.com/news/magazine-14713523

${ }^{77}$ | bid.
} 
Go put bangles on, like women do

Pick a pot like women do and bring water

If you are not going to fight, what is the use of your long hair?

All you do is eat - and that is all

When I found about your martyrdom, tears started flowing down from my eyes

Your death engulfed me with sorrow, there were cries throughout Laghman

I tried to calm myself, but I cannot do it

By God, I cannot bear this

These hymns clearly call upon youth to take up arms and join the ranks of Taliban in order to fight the infidels. In the first hymn, the Taliban has compared the young men with women who do not take part in the fight alongside Taliban. Young people living in a patriarchal society like Afghanistan would never like to be compared with women, therefore, these hymns are designed to stir up their emotions and encourage them to join the Taliban in order to prove their bravery.

\subsubsection{Increasing visibility and the international community}

As mentioned earlier, the Taliban does not have regular and reliable media facilities such as TV, radio or print that would enable them to spread their messages. There are evidences that the Taliban have mobile radio stations in limited places. However, a major tool for disseminating radical ideology, which is also their most efficient, safest and cost effective way of spreading their messages, is via hymns. They send clear messages to the Afghan government and the international community about several issues, including why the Taliban are fighting against them. One of their hymns that explains to the international community why the Taliban are fighting against them is as follows:

I spend secretly nights in dark mountains

And yet, you blame me

My house has been bombarded and my children became displaced

And you the people of this world still blame me

These aliens have invaded my home

They force me to part ways with my religion

They destroy my homeland

You invaders

This may be a small thing for you but it is important for me

And you the people of the world still blame me

In this hymn, the Taliban have clearly stated that the international forces have invaded Afghanistan, bombarded the houses of many Afghans and have tried to change their beliefs. The Taliban have also tried to highlight that the main objective of the foreign forces is not to bring peace, but it is something clandestine. They base their reasoning on this fact and justify jihad against the foreign forces.

The Taliban, in another hymn, talk of their success against the foreign forces. The Taliban try to state to the people that they are strong and capable to fight both the Afghan forces and their international backers and are succeeding. 


\subsubsection{Remembering and glorifying their dead members}

Taliban hymns also glorify martyrdom operations as one of the biggest achievements and a proud moment for its members. For example, the following hymn glorifies a now-dead Taliban commander, Commander Mullah Shehzad who was killed in the Nowzad district of Helmand province:

Hey tomb, you should not forget these dears of us

You should not forget Mullah Shehzad, our success

A white rose has come out from the heart of Nowzad

$\mathrm{He}$ is the result of suppression and invasion

He has sought refuge in your arms

You should not forget the warrior and the passenger

You should not forget Mullah Shehzad, our success

In this hymn, the Taliban speak with pride for

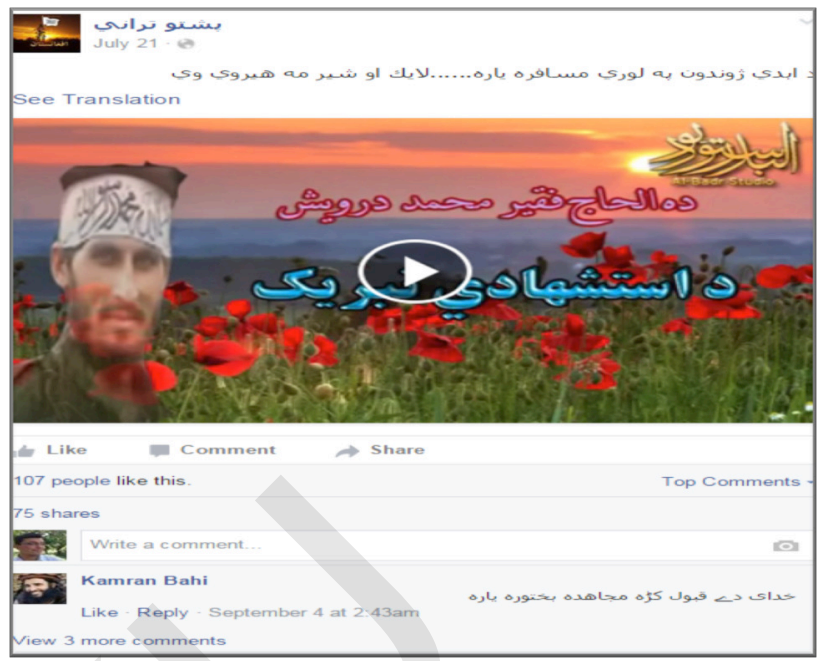

Screenshot 12 - A Facebook page full of Taliban songs glorifying its dead members and spreading the propaganda against the Afghan government and its their dead commander. The hymn refers to the commander as a martyr and claims that this is the best way to die. The Taliban have also tried to convince others that fighting against evil is their duty and that paying the dead their due is also their obligation. Similarly, another part of this hymn is dedicated to praising the warriors. For instance:

Oh the passenger of high mountain that is struck by strong winds

I sacrifice myself for you

I sacrifice myself for the soldier of the religion

You have suffered a lot

I sacrifice myself for you

But each time, you have been to the battlefield, I sacrifice myself on you

You have been the defender of the helpless

I sacrifice myself for you

You have been the soldier of the religion

You have kept the suppressors honest

I sacrifice myself for you

You are a soldier of the religion

I sacrifice myself for you.

Again, in this hymn, there are important references to the battlefield and how people are encouraged to take up arms and go to the battlefield. It praises those who have suffered and spent difficult times in the battlefield, but still did not betray their cause. In this hymn, those who defend the subjugated are 
referred to as the savior of the helpless. This implies the Taliban see their fighters as fighters and champions who defend the poor and helpless against the government and foreign security forces.

\subsection{People's perceptions about the radical narratives in social media}

This section highlights the perceptions and experiences of active Afghan social media users about the radical narratives articulated through social media across 4 cities of Afghanistan - Herat, Jalalabad, Kabul, and Mazar-e Sharif. It is based on 72 in-depth semi-structured interviews with individuals comprising of academicians, journalists, civil society activists, religious leaders, university students, and government and security officials. It is worth mentioning that the 72 active social media users interviewed do not represent the whole population of social media users in Afghanistan, but provides a sample of people's perceptions about the different kinds of radical narratives on social media.

\subsubsection{Use of social media in Afghanistan}

The most popular social media platform amongst interviewees is Facebook followed by Twitter, Youtube, Instagram and Google Plus. The social media users interviewed in Herat, Jalalabad, Kabul and Mazar-e Sharif mainly use Facebook to stay in touch with family and friends, in addition to following news and current affairs as well as exchanging views on social and political affairs. Only a very small number of participants in Jalalabad believed that social media is used for social and political mobilization such as organizing rallies in Afghanistan. Some of the students interviewed in Jalalabad noted that they use social media to connect with some well-known academics in the Western countries, whereas a few others actively participate in various forums to counter dissemination of radical ideologies. In Kabul, Mazar-e Sharif and Herat, the people interviewed mainly use social media to track news and current happenings, discuss and debate various socio-political affairs and interact with family and friends.

With the increase in the usage of internet in Afghanistan, the dependence on social media has also increased. Respondents in all the four cities suggest that young educated people rely on social media to a great extent for news updates and can easily get influenced by various radical narratives trending on social media. For example, a lecturer interviewed in Jalalabad, claimed that in 2014, he observed a drastic change among young people in his community during the protracted presidential election crisis. This statement was confirmed by a few other lecturers in Jalalabad who said that Facebook was earlier considered as an entertainment tool but now people have started discussions on political issues and it started after the confusion over presidential elections continued for several months. In other words, the 2014 elections marked a turning point in the rise of social media as a medium of social and political mobilization in Afghanistan.

One of the teachers in Jalalabad suggested that it has become a normal practice for young students to visit different social media platforms and claimed that $100 \%$ of the students active on social media are influenced by radical ideologies in some way or the other. He further added that the youth in the city are generally seen liking and commenting on the posts by some well-known figures on Facebook and that the majority of them share the posts of other users without verifying their contents. Several other 
interviewees suggested that youngsters are manipulated by various radical elements on Facebook and other platforms of social media and unconsciously form opinions in line with the radical elements. While replying to the question, whether social media is used for social mobilization in Afghanistan, the majority of the respondents in Jalalabad claimed that social media is not used as a tool for social change or mobilization in Afghanistan but it is used merely as a tool for entertainment and news sources. However, a few respondents in the city claimed that in the past social media has been used in the city for announcing protests, such as rallies against electricity blackouts and protests against the burning of the Quran. In Herat and Kabul, the social media users interviewed are actively using social media for social mobilization by announcing planned public events on Facebook and Twitter. They find it easy to inform like-minded people of various backgrounds via social media and discuss the various problems faced by the people. One of the civil society activists in Herat claimed that he along with his friends use social media to bridge the gap between liberal and religious people, whereas some of the respondents in Mazar claimed that they make efforts to expose the people using fake accounts to counter radical ideologies. One of the civil society activists interviewed in Mazar said that he uses social networks in cooperation with various local civil society organizations to mobilize people and raise awareness against the radical elements both on ground as well as on social media.

\subsubsection{Use of social media by radical elements}

Only a few respondents in all the four cities believed that radical groups use social media for the purpose of recruitment. However, there is general consensus among all social media users interviewed that radical elements use social media mainly for garnering support for their causes, with some success. One of the journalists interviewed in Kabul claimed that social media is mostly used for brainwashing and recruiting youngsters for violent actions for different causes. He was referring to the Daesh online campaign for recruiting a number of foreign fighters for their cause. In his opinion, the Taliban has also used social media for recruitment purposes ${ }^{78}$. He warned that if the Afghan government does not implement a proper policy to curb the activities of radical elements on social media, it could pose serious problems for the future of Afghanistan. A student and a government employee interviewed in Kabul claimed that radical elements create fake accounts using fake pictures and names of girls to recruit youth. These account holders portraying as girls try to be very attractive to young men while disseminating radical ideas until they succeed in convincing the young people to join their cause.

A researcher interviewed in Kabul said that the radical groups propagate messages relying on ideas deep rooted in religious texts of Muslims. He noted that terms such as jihad and kafir and sentences such as 'Islam is in danger' are commonly found on the social media pages belonging to radical elements mainly aimed at motivating young people to join their cause. He argued that radical elements may not seem to be openly recruiting people for their cause but their messages are very clear. He

\footnotetext{
${ }^{78}$ Wais Barakzai, Jalb Wa Jazb Baraye Daesh Az Tariq-e Facebook (Recruitment by ISIS Through Facebook), Official Facebook Page, https://www.facebook.com/WaisBarakzai/videos/vb.367376293298903/891482617554932/?type=2\&theater, Accessed on August 7, 2015
} 
further added that the radical groups not only want sympathizers and supporters but also seek people who will fight alongside them on the ground.

\subsubsection{Respondents' exposure to radical narratives in social media}

The majority of the respondents in all four cities claimed that they notice radical messages in social media on a daily basis. There are mainly two types of radical messages noticed by social media users in Afghanistan - religious radical messages, which call for jihad and establishment of an Islamic State, and ethnic radical messages, which incite ethnic hatred among various ethnic groups of the country. There are significant variations in the types of radical ideas being experienced through social media across these cities. The respondents in Jalalabad claimed that they come across radical narratives being spread by religious radicals, whilst respondents in Kabul and Mazar-e Sharif were also exposed to radical messages targeting various ethnic groups on social media with the aim of inciting ethnic hatred. By contrast, respondents in Herat claimed that in addition to radical religious and ethnic views, they come across radical narratives from secular people as well,

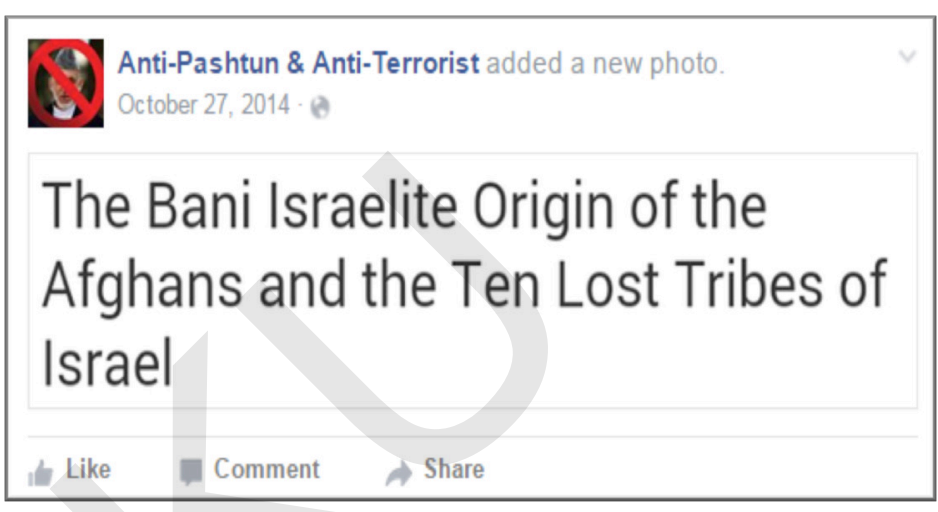

Screenshot 13 - A fake Facebook account spreading ethnic hatred against the Pashtuns by comparing them with terrorists who openly criticize religious beliefs. The religious messages mainly call for the establishment of some form of an Islamic state, including Caliphate, and war against infidels, Hijab for women, and condemning the US-led NATO operations in Afghanistan and other Muslim countries across the world. Some of them are focused on condemning media for programmes that are against the Islamic values.

There are several other topics discussed on social media regarding the political, social, cultural and ideological beliefs of different groups. A civil society activist from Herat claimed that the supporters of Ashraf Ghani and Abdullah Abdullah are spreading hatred between Pashtuns and Tajiks due to various disputes between the President and CEO of the National Unity Government (NUG). In addition to this, the respondents in Herat believed that there are some serious tensions between modernists and traditionalists because of their ideological differences.

A civil society activist interviewed in Mazar claimed that the radical groups mix-up religion and ethnicity. He described messages against Pashtuns labeling them as suicide bombers while members of other ethnic groups are blamed by some for being too liberal, or even for converting people to Christianity. Another civil society activist interviewed in Mazar claimed that in order to spread hatred among different ethnic groups, radical groups upload photo-shopped images to show certain ethnic groups in a bad light. Some respondents belonging to Shia Hazara community claimed that their community is specifically targeted. 
However, respondents in all the four cities agree that radical groups mainly target the Afghan government and international community. This view was confirmed by several people interviewed in Herat who believed that the radical groups do target certain ethnic groups but their main target is to spread hatred against the Afghan government in order to weaken it. Several other respondents from both Mazar and Herat claimed that radical groups target women and are against co-education in educational institutes.

A journalist interviewed in Kabul claimed that he is not directly exposed to radical content on social media; however, he believed that his friends are exposed to such content. According to him, the radical content on social media varies as some people express their radical views by engaging in debates where extreme and fundamental views are expressed, whereas others constantly post, like, share and comment on some well-known radical websites and social media pages, in addition to uploading and sharing violent graphic content on their personal Facebook pages. This indicates that the radical groups or individuals do attract social media users by drawing them to engage in actual debates on the content they produce and share on various social media platforms. None of the other respondents explained this and it is something that needs to be investigated further in future researches.

The majority of interviewees also believed that the easiest and the most effective tactic used by radical individuals or groups to gain support is to manipulate religious teachings to their causes. For example, a teacher interviewed in Jalalabad claimed that extremists circulate violent messages and refer to the Quran after completely misinterpreting the religious texts. He further added that various radical groups are targeting young people, who easily fall prey to their false propaganda because of the lack of strong public awareness programmes in Afghanistan. All respondents agreed that young people are the main target of radical groups and individuals. Several interviewees claimed that the radical messages on social media platforms have increased in the past couple of years. They suggested that issues such as nonIslamic nature of the Afghan government, violation of the teachings of Islam by empowering women and promoting secularism, non-compatibility of several TV shows with Islamic values are used by different radical individuals and groups to justify their ideas. One respondent claimed that most of the radical pages are operated through unidentifiable users. Being anonymous and using fake accounts makes it easy for radical elements to disseminate any kind of radical content without putting themselves at any risk. For example, a religious leader interviewed in Jalalabad claimed that despite working with the Afghan government and civil society organizations, there are some people who anonymously on social media refer to the US presence in Afghanistan as invasion by infidels. These pages directly call for war against the US and international community's presence in Afghanistan.

All the respondents claimed that the radical narratives are mainly targeting specific groups of people who believe in the Western style democracy and socio-political freedoms. A few respondents suggested that whether it is a secular radical group, an ethnic radical group or a religious radical group, anyone who opposes their ideology becomes the target of such radical groups - suggesting that the targeting of such narratives is less directed and more free-flowing. All these radical groups encourage young people to become more conservative towards people belonging to other religions or ethnicity. 
The majority of the respondents believed that the radical groups do not directly call for violent actions. They suggested instead that the process starts with the invitations to the people to support their causes, which is considered as the first step towards radicalization. However, many respondents pointed out that pages run by anonymous users are more likely to call for jihad and violent action against the state, international community's presence in Afghanistan and anyone who supports the government or US lead NATO forces. These pages mainly claim that the violent action against the secular nature of Afghan government officials is religiously justified. In addition to this, they criticize and blame the Afghan government by pointing out the weaknesses in the current political setup and criticize it on its good ties with the non-Islamic countries.

One of the respondents in Mazar claimed that he was invited by radical elements via social media to work for their Facebook group as a campaigner and was later threatened for refusing to do so. However, a journalist interviewed in Kabul had a different view about the radical content online. He claimed that it has been observed that very little of the proactive content on the social media actually results into offline action. He argued that social media has made young people in Afghanistan very lazy as they vent out anger and frustration online but keep going on as usual in their daily lives. However, that makes it very easy and convenient for hate mongers to spread and motivate the youth by mere liking and sharing content, which has become a kind of addiction for some social media users in Afghanistan.

A group of people belonging to Shia-Hazara community in Kabul claimed that they come across religious as well ethnic radical narratives. They were of the view that these radical elements sometimes mix religion with ethnicity and culture. Citing the celebration of Nowruz as an example, the respondents said that the religious radicals condemn the celebration of Nowruz as well as the people belonging to Dari speaking Tajik and Hazara ethnic groups. Moreover, the respondents stated that there are some people who criticize religion openly in their posts on social media, which creates tensions among the religious people both moderates as well as extremists. For example, a scholar, considering himself secular, had posted an article on his Facebook page, in which he argues that the war between Imam Hussain - the grandson of Prophet Muhammad and Yazeed Bin Maviah - son of Amir Maviah at Karbala was not a holy war but a mere struggle between two families to gain power. According to the social media users interviewed, the arguments like these hurt the sentiments of believers of Islam, especially the Shia community to whom Imam Hussain is very dear.

\subsubsection{Public and civil society response to radical messages in social media}

The respondents outlined a variety of responses to radical messages on social media. Some respondents said that they openly argue with the radical individuals or groups. A business consultant interviewed in Jalalabad claimed that he takes part in various discussions led by the radical groups or individuals and openly criticizes their ideology. In Herat, only a few respondents said that they ignore the radical messages. The majority of the respondents claimed that they immediately reject any kind of radical narrative and promote moderate ideas on social media. For example, a civil society activist interviewed in Herat claimed that he regularly tries to get in touch with different people both radical as well as moderate in order to spread moderate views about religion. Some of the interviewees in Mazar react to messages, which are intended to spread hatred among various ethnicities in Afghanistan, whereas others 
claimed that they tried to argue logically with Taliban supporters, but noted that the Taliban members are not interested in reasoning and as such any attempt to argue with the Taliban is simply a waste of time.

Some respondents chose to argue openly with accounts belonging to genuine social media users only. These respondents noted the dangers of responding to anonymous users. For example, criticizing the radical narratives is considered dangerous by one of the teachers interviewed in Jalalabad. Similarly, an academician interviewed in Kabul also avoids replying to the messages posted by people with fake identity but responds to the radical messages posted by people with a verifiable identity. He believes that criticizing anonymous radical posters openly is a huge risk given the fact that it could be anyone living in one's neighborhood. However, a lecturer in

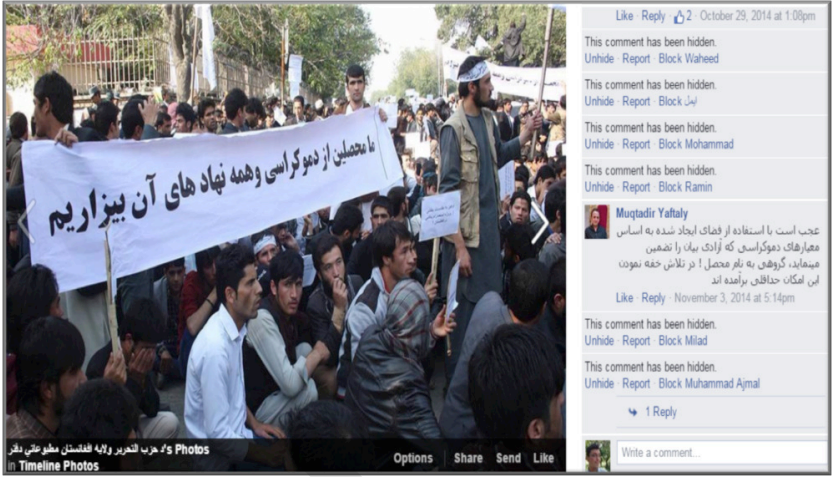
Screenshot 14 - A picture posted by Hizbut-Tahrir on its official Facebook page, showing a gathering of University students condemning democracy with a comment from a moderate social media user saying, 'it is odd to see students using democratic environment to destroy democracy Jalalabad claimed that the radical messages are intriguing and argued that some people cannot avoid taking part in discussions in the comments section of posts on Facebook despite the risks involved in doing so.

A group of respondents have adopted a different strategy that is to ignore all kinds of radical contents as a way of minimizing their impact on society. For example, a civil society activist interviewed in Herat said that he deliberately ignores the radical content on social media. According to him, the radical elements want attention and reactions from the people to gain popularity. He suggested that the best way to deal with such people is to ignore their messages. This view was supported by a civil society activist from Mazar as well as a journalist in Kabul, who believed that the best way to counter any radical group or individual on Facebook or any other social media platform is to ignore or block them. This way the people can put a check on radical messages from going viral every time.

Another groups of respondents have adopted a completely different approach to counter radical narratives in social media. For example, a respondent interviewed in Herat claimed that he denounces any form of radical messages on social media, whether it is against the Afghan government, against the people who strongly believe in the internationally accepted norms of democracy and human rights, or if it is a message from liberals intended to hurt the sentiments of religious people. Whereas, a women right's activist in Herat publishes posts on her Facebook and Twitter accounts with references from religious texts and international law to promote women rights in Afghanistan and a civil society activist interviewed in Mazar claimed that he tries to highlight the challenges Afghanistan is currently faced with the historic facts. He has adopted this way to counter radical narratives targeting any group or individual 
in social media. According to him, it is important to remind people about the repercussions of violence as well as the ideas that could potentially lead to violence.

However, there was a consensus among the respondents in all the four cities that there is no collective effort being made to counter the radical narratives on social media. Respondents noted that individuals from government, civil society, well-educated youth and academicians do tackle these narratives online and named a number of individuals. ${ }^{79}$ These individuals actively participate and oppose various radical narratives trending everyday on social media and condemn any terrorist attack on Afghan soil. In addition to this, these individuals promote messages that support democracy and women rights. A respondent from Kabul noted that individuals like Wais Barakzai who has a lot of followers on social media for his active role in bringing reality checks to provocative content - also tries to rally people around happy moments of unity by sharing sports victories, etc.

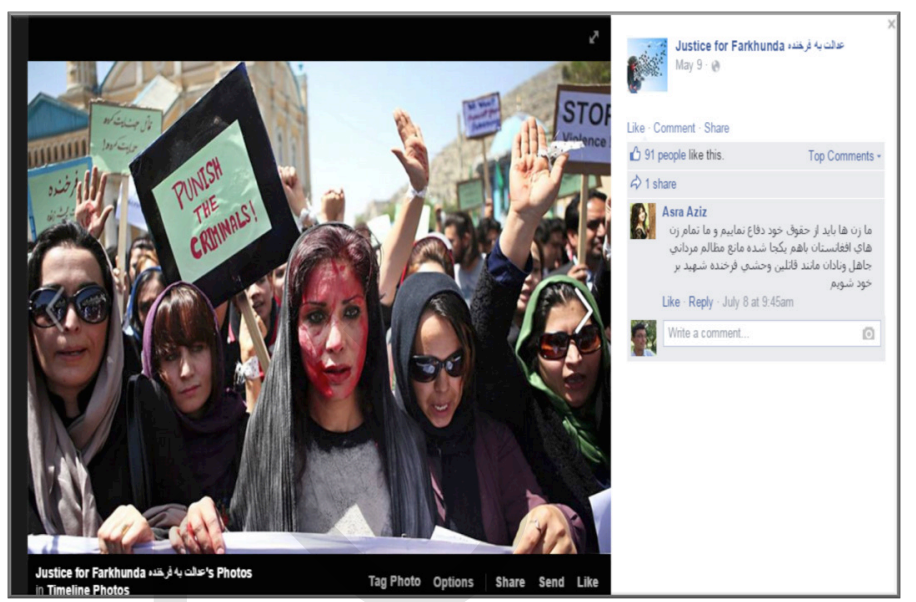

Screenshot 15 - A Facebook page created by some civil society activists demanding justice for Farkhunda

A few respondents also believed that Afghans are uniting against the threats coming from neighboring countries which is evident from various responses posted on social media immediately after an attack is carried out in Afghanistan. Any individual seen supporting Pakistan or Iran on social media is condemned immediately and there is a feeling of hatred seen amongst the general public against them for their negative role in Afghanistan. For example, a local organization named 'Positive Society Change' and some individuals such as Hijratullah Ekhtyar, Abdul Saboor Mubariz, Syed Shinwari, Engineer Zaheer, Mujib Lemar, and Shapoor Bakhtiyar, supported the 'Boycott Pakistan and Pakistani Products' campaign on Facebook for Pakistan's association with a bomb blast in Kabul. ${ }^{80} \mathrm{~A}$ researcher interviewed in Kabul cited an example of a Facebook page titled 'Afghanistan My Passion' which called for boycotting Pakistani products in Afghanistan in response to Pakistan's alleged involvement in various bomb blasts across Afghanistan. He further noted that the use of the 'bringback 31 hazaras' hashtag by social media users mobilized people across the country and forced the government to make necessary steps to bring back 31 Hazaras kidnapped by some unknown gunmen in Zabul in February $2015 .{ }^{81}$

\footnotetext{
79 Wais Barakzai, Inayatullah Kaker, Hamdullah Arbab, Daud Wafa, Aimal Pasarly, Matiullah Abid, Dawlat Waziri, Bakhtiyar Talash, Abdul Fatah Jawad, Khoshal Khalel, and so on.

80 Mokhtar Wafayi, Afghans Boycott Pakistani Goods Over Taliban Claims, The Observers, August 20, 2015, http://observers.france24.com/en/20150820-taliban-attacks-afghanistan-boycott-pakistan-goods

${ }^{81}$ Afghanistan Kidnap: Gunmen Seize 30 Hazara Men in Zabul, BBC, February 24, 2015,

http://www.bbc.com/news/world-asia-31600476
} 
Other respondents claimed that social media helps in raising the awareness among the people of Afghanistan about daily social and political affairs, with several respondents citing the example of the Farkhunda protests, which emerged after the murder of an Afghan lady named Farkhunda by a mob for allegedly burning a copy of the Quran. ${ }^{82}$ In another example, several respondents noted the 'Kabul Taxi' incident. Here, government forces questioned some journalists for their alleged links to the 'Kabul Taxi' page- a satirical Facebook page that criticizes the Afghan government for its failure to curb violence, rising unemployment, corruption, a floundering economy and so on. ${ }^{83}$ In reaction to this, social media users across the country condemned the government for trying to curb the right to freedom of speech.

Other interviewees suggested that a number of social media users actively oppose all kinds of radical ideologies. For example, the Imam of Herat's grand mosque, Mujib-ur Rehman boycotted the music concert of a young Afghan singer, Shafiq Murid. ${ }^{84}$ After the word spread out, community members took to social media and condemned the boycott call by the Imam. Social media users in Herat also claimed that they condemn any inhuman activity as well as the people who support it. Some respondents also believe that women rights are gaining a lot of support on social media, citing an example of Seema Jowenda, who was appointed as the governor of Ghor province. ${ }^{85}$ Some radical elements including a few Mullahs had criticized her appointment, however, a number of people supported her appointment via social media, posting messages in favor of women rights and condemning the people who opposed her appointment. Similarly, in a patriarchal society like Afghanistan, women are regularly victims of domestic violence in a number of cases across the country. However, respondents suggested that with the advent of social media, people have started condemning such violence. For example, social media users interviewed in Herat gave an example of a man who cut the nose and lips of his wife after she refused to sell her jewelry to pay for his drugs. ${ }^{86}$ The act was widely condemned by the social media users across the country and some people also came forward to financially help the lady with the expenses for her treatment.

\footnotetext{
${ }^{82}$ Zarghuna Kargar, Why was a Young Woman Killed by a Mob in the Streets of Kabul? ,Prospect Magazine, August 4, 2015, http://www.prospectmagazine.co.uk/world/why-was-a-young-woman-killed-by-a-mob-in-the-streets-ofkabul-farkhunda-afghanistan

${ }^{83}$ SudarshanRaghavan and Mohammad Sharif, Afghan Flock to Kabul Taxi, a Satirical Facebook Page that Spares no one, The Washington Post, July 11, 2015, https://www.washingtonpost.com/world/asia_pacific/afghans-flock-tokabul-taxi-a-satirical-facebook-page-that-spares-no-one/2015/07/11/64d17208-2737-11e5-b621b55e495e9b78_story.html ${ }^{84}$ Concert-e Shafiq Murid Dar Wilayat-e Herat Laghw Shod (Shafiq Murid's Concert Cancelled In Herat), Shabake Etela Rasani Afghanistan, http://www.afghanpaper.com/nbody.php?id=40359, August 20,2012

${ }^{85}$ Reshad Shokoh, Bargozari-e Tazahorat Dar Mokhalifat Wa Hemayat Az Sima Joyandah Wali-e Ghor, Ufuq News Agency (Protest against and in favor of Seema Joyenda, Governor of Ghor), October 18, 2015 http://www.ufuqnews.com/archives/21181

${ }^{86}$ Syed Zafar Mehdi, 'Refused Money to Buy Drugs, Husband Chops off Wife's Nose, Lips', Afghan Zariza, December 18, 2013, http://www.afghanzariza.com/2013/12/18/refused-money-to-buy-drugs-husband-chops-off-wifes-nose-lips
} 


\subsubsection{Government response to radical narratives and counter radicalization approach}

In addition to the interviews with individual social media users, we conducted interviews with the senior officials of the Ministry of Defense (MoD), Ministry of Interior (Mol), National Directorate of Security (NDS), Ministry of Communication and Information Technology (MCIT), and Ministry of Information and Culture (MolC). All of these ministries use social media for organizational purposes to broadcast their activities and programs, in addition to staying connected with the general public. Out of the five ministries mentioned above, Mol, MoD and NDS monitor social media for security purposes. However, NDS is the main body responsible for monitoring social media regarding the dissemination of radical messages online whereas, Mol and MoD are mainly responsible for monitoring social media to address public questions and complaints, in addition to dealing with the false propaganda being disseminated by radical groups against the Afghan government.

A senior official from Mol claimed that Mol has a monitoring department to keep track of various activities taking place on social media, but they do not conduct any investigations or control any content, rather they only track events taking place in social media and try to address the questions raised by the general public.

NDS closely monitors radical groups and individuals spreading hate messages on social media across Afghanistan. According to a senior official from NDS, Daesh, Hezbut-Tahrir, Uzbekistan Islamic Movement (UIM), and the Taliban are the most active radical groups using social media. In addition to keeping a close eye on such radical groups, the NDS keeps track of social media pages and websites belonging to other Islamist groups, such as Jamiat-e Islah and Hezbut-Tahrir monitoring their pages for any evidence hinting towards their involvement in any violent activities. ${ }^{87}$ NDS considers Daesh the leading campaigner of disseminating radical ideologies as well as recruiting people online, followed by UIM and Taliban. The official noted that the Taliban had changed tactics to cope with the rise of Daesh. Earlier, the Taliban were seen as effective users of mass media such as, radio, pamphlets, and websites for recruitment, but with the rise of Daesh propaganda in Afghanistan, the Taliban has increased its social media recruitment campaigns.

A senior official interviewed in the MoD said that the MoD fully cooperates with the NDS in monitoring the radical content targeting the Afghan government on various social media platforms.

In August 2015, NDS released a video of some Afghan Daesh affiliates acknowledging that Daesh members through Facebook recruited them. According to the NDS, Daesh has recruited some Afghan girls living in Kabul to join their ranks in Syria. However, there is no evidence yet to establish that the propaganda material is produced in Afghanistan. Citing an example, a senior official in the NDS said that the video clips of Hafez Saeed - the Daesh appointed governor of Welayat-e Khorasan, killed earlier this year - were produced in Pakistan and posted on through Daesh main social media pages in Iraq. The other example is of a video posted by Daesh in August 2015, showing the execution of some Afghans by Daesh members. Daesh had claimed that they carried out the executions in the Nangarhar province of

${ }^{87}$ Interview with a senior NDS official, September 2015. 
Afghanistan. However, after thorough investigations by the NDS Afghanistan, it was revealed that the video was shot in Pakistan and the people killed were not Afghans.

All the three ministries responsible for security in Afghanistan claimed that the main sources of radical ideologies are the armed radical groups, such as Daesh and Taliban. It was revealed during the interviews that NDS and $\mathrm{Mol}$ are more concerned about religious radicalization trends whereas, the MoD is worried about the ethnic and linguistic tensions among the Afghan National Security Forces (ANSF).

In an interview with a senior NDS official, he claimed that NDS is committed to track down radical as well as terrorist groups. However, he refused to disclose the current strategies or the strategies NDS has adopted in the past to counter radicalization trends in Afghanistan. NDS claims that the Afghan intelligence agency is one of the best in the region; however, NDS lacks support from other government organizations in Afghanistan, which hampers their efforts to track down the radical elements within Afghanistan.

A senior official of the MCIT claimed that the department works closely with NDS to track down any group or individual disseminating radical ideology via social media. The MCIT has cooperated with Interpol, NDS, courts of law and general attorney in the past to track down the radical individuals and groups. In one case, after receiving an official order from NDS, the MCIT took legal action against some social media users who were propagating false and disturbing propaganda about the death of Marshal Fahim, former deputy of president Karzai who died in 2014, by identifying and shutting down their propaganda pages in social media. ${ }^{88}$ The official interviewed, however, admitted that despite such successes, there are several shortcomings that need to be addressed in order to implement the cybercrime law. According to another senior official, the MolC has recently included social media under the mass media law. Based on this definition, all the complaints made against certain individuals or groups on social media will be addressed as per law. MolC is also preparing a code of conduct for the journalists in Afghanistan to make sure that the mainstream media personnel do not disseminate radical ideologies consciously or unconsciously by sharing hate messages on media platforms including social media. A senior official from the MolC claimed that in order to promote freedom of speech and to defend the status of journalists, the ministry has created a number of commissions, including a commission for ease of access to information, commission for preventing violence against journalists, commission for defending the legal status of journalists and commission for drafting code of conduct for journalists. Such legal steps provide journalists with a freedom to express their ideas on various media platforms including social media and at the same time ensure that the journalists do not spread hate messages in any form. However, there are no visible official policies formulated by the Government of Afghanistan to counter radicalization or radical narratives in Afghanistan including social media.

\footnotetext{
${ }^{88}$ Interview with a senior MCIT official, September 2015
} 


\subsubsection{Respondents' views about government policies for counter radicalization}

The majority of the respondents in all the four cities pointed to a lack of government policies to counter radicalization in social media. One of the teachers interviewed in Jalalabad said that apart from a few TV advertisements that aim to raise awareness among the public, there is no particular policy adopted by the NDS to track down the people spreading radical narratives or to counter radicalization before it goes out of control. This view was supported by the respondents in Mazar who believed that the lack of proper policies to curb radicalization gives the radical elements a free hand. A teacher from Jalalabad argued that the problem lies within the system. In his opinion, recently several people spreading radical messages have been tracked down and arrested by the NDS, which means that the government is reacting too late to stop radical people from disseminating radical ideologies. A government employee from Kabul held similar views saying that the government tries its best to curb the spread of radical ideas by frequently blocking or removing Taliban's Facebook as well as Twitter pages but that is by no means a counter radicalization policy. Some of the respondents claimed that the anti-terrorism policy acts as a deterrent to radicalization to some extent, but the Afghan government still needs to take some effective measures to counter radicalization. A women rights activist interviewed in Kabul also claimed there is no existing official policy to counter the impact of radicalization through social media. He advocated for a national strategy to prevent the violent extremism.

Some of the respondents put forth some suggestions for the Afghan government to counter radicalization on social media. For example, one of the respondents from Mazar suggested that the government should create citizen-reporting centers, wherein Afghan people can complain about any individual or group promoting radical ideas on social media. Another respondent suggested that the government needs to first curb corruption within its own bodies before it can help the Afghan people fight with the radical elements. A few others believed that the Afghan government is quite weak and needs to adopt a long-term strategy to control the dissemination of radical ideologies on social media. Interviewees in Kabul recommended that the government should create a special Ministry for Youth, which would primarily look after the problems of young people in Afghanistan and implement effective strategies to prevent youth from falling prey to the false propaganda of various radical elements.

The social media users interviewed in this study were not satisfied with the approach adopted by the Afghan government to counter radicalization, with the majority of them suggesting that there is no existing official policy adopted by the government to counter radicalization especially on social media. 


\section{CONCLUSIONS AND RECOMMENDATIONS}

Afghanistan's online communication sector is growing rapidly, with profound social, political and security consequences. The full impact of the exposure of the Afghan society to the forces of globalization through the internet will become apparent over the period of time. However, what is already evident is that various social and political groups, including radical, moderate, violent and peaceful actors, have proven to have a high adaptive capacity to embrace the changes in communication technology.

This study focused on the articulation of religiously-motivated ideological and political narratives through social media platforms in Afghanistan. It monitored social media contents of a selected number of peaceful Islamic activist groups as well as the known militant groups. The peaceful Islamic activist groups identified narratives that are formulated around social, cultural and political concerns of peaceful activist groups such as Jamiat-e Eslah and Hizbut-Tahrir. On the other hand, militant groups explored more violent narratives and rhetoric of armed groups such as the Taliban, the militant Hizb-e Islami and the Daesh. While the peaceful groups have some significant ideological and theological commonality with the violent groups, but they do not always pose any immediate security concerns. Having said that, the socially conservative sections of the society and peaceful religious activist groups can contribute to the goftar; and discursive aspects of radicalization and as such should be conceived as the base of the radicalization pyramid. The narratives of peaceful groups combine genuine social and political concerns such as frustration and anger with corruption in the Afghan government with varying degrees of radical narratives and worldviews. By contrast, militant groups also compete for the support of the conservative sections of the society but are primarily focused on a violent and armed strategy in pursuit of their social and political agendas. The key point is that both groups converge on important respects on the sociocultural and political narratives about the post-2001 Afghanistan, albeit one narrative is focused on foreign 'cultural invasion' and the other on Western military and political intervention.

However, religion based radicalization should be seen as only one form of a broader phenomenon of intolerant and violent ideologies and behaviors. As some of the respondents in this research emphasized, radicalization should be seen as part of the broader process of behavioral and ideological tendencies. Consequently, while it is important to recognize the risks of religion based radicalization in Afghanistan, other forms of radicalization, including those inspired by ethnic, nationalist and secular ideologies, may pose equally serious and challenging risks. Many respondents pointed to the diffusion of hatred, intolerant ideologies and violent narratives by ethno-nationalist users across the Afghan social media milieu as another type of radicalization.

While social media can arguably be accessed and utilized by both radical and militant, conservative and liberal groups, the former appear to have some specific incentives to outperform the latter in making more effective use of these technologies. Radicalization by definition means that individuals and groups subscribing to radical ideologies are prepared to spend greater amount of time and resources to advance their specific ideological and socio-political causes in comparison to moderates. By comparison, moderate groups and individuals are likely to have more diverse interests, which also explains the comparatively greater appeal of moderate social media profiles focusing on broader range of issues. 
This means that in comparison to moderate groups and individuals who make use of social media for various purposes, ranging from entertainment and personal communication to political debates, radical groups have greater incentives to outperform others in single-mindedly using the technology to share and promote particular ideological and political narratives.

Consequently, the Afghan social media space is a mirror of the strategic social and political environment of Afghanistan, which is characterized by decades of foreign interferences, ongoing war and violence, and profound social distrust and suspicions. The continuation of armed conflict in post-2001 means that images of war and violence are shared and viewed in high frequency by social media users even if they are not subscribing to militant and radical worldviews.

In view of the risks and opportunities presented by the recent expansion of social media, the Afghan government should take initiatives to harness its potential for positive social and political change. First, it should formulate and implement a counter-radicalization policy that addresses different aspects of radicalization as a social and political process, including its diffusion of radical ideologies through social media. Second, it should broaden the scope of the current discussion on regulation of social media by engaging Afghan civil society, educational institutions, Islamic activist groups and media organizations. A future legal and regulatory framework concerning social media should find a balance between regulation of social media and concerns about restrictions of freedom of expression.

Social media is still a novel - though rapidly expanding - phenomenon in Afghanistan. Its broader social and political impact, including its role in radicalization process may become more apparent over the period of time and as a result the international community should support the country by supporting research studies and providing advice and technical expertise for devising appropriate policies to counter radicalization in Afghanistan.

Finally, with the adoption of modern technologies, as part of the organizational and social mobilization strategy, the radical and militant groups must be seen with significant concern. However, the picture of Afghan social media is not all gloomy and dark. Interviewees noted that media and mobile phone technologies are fast becoming important tools for social and political mobilization by various groups that aim to counter militant and radical ideologies and by civil society activists who advocate for social and political reform. In short, social media is emerging as a new field of contestation among various social and political groups with significant consequences for the future of the country. 


\section{REFERENCES}

Aabed, A., Chigona Az Quran Defa Konim? (How to Defend Quran?), Eslah Online, https://www.youtube.com/watch?v=YLKmqQevncg, Afghanistan, Accessed on March 16, 2015

Aabed, Aya Hizb-e Islami ta Mansob Nor Dawlati Mamorin ba Estefa Wokri? (Should the Members of Hizb-e Islami in Governmental Positions Resign?), Daily Shahadat, Afghanistan, June 23, 2015,

http://www.dailyshahadat.com/site/lekani_details/1106

Afghanistan Kidnap: Gunmen Seize 30 Hazara Men in Zabul, BBC, February 24, 2015, http://www.bbc.com/news/world-asia-31600476,

Asef Maruf, Jabh-e Jang-e Tablighati-e Taliban (Taliban's Propaganda War Front), BBC Persian, October 2, 2015, http://www.bbc.com/persian/afghanistan/2015/10/151002_taliban_propaganda_war_asif_maroof

Awan, A. N., Radicalization on the Internet? The Virtual Propagation of Jihadist Media and its Effects, RUSI, June 2007, https://www.rusi.org/publications/journal/ref:A46728254DE4AE/\#.VhzkAuyqpHw

Barakzai, W., Jalb Wa Jazb Baraye Daesh Az Tariq-e Facebook (Recruitment by ISIS Through Facebook), Official Facebook Page, https://www.facebook.com/WaisBarakzai/videos/vb.367376293298903/891482617554932/?type=2\&theater, Accessed on August 7, 2015

Berger, J., \& Morgan, J., The ISIS Twiter Census: Defining and describing the population of ISIS supporters on Twitter, Brookings, March 2015, http://www.brookings.edu/research/papers/2015/03/isis-twitter-census-bergermorgan

Concert-e Shafiq Murid Dar Wilayat-e Herat Laghw Shod (Shafiq Murid's Concert Cancelled In Herat), Shabake Etela Rasani Afghanistan, http://www.afghanpaper.com/nbody.php?id=40359, August 20,2012

Carr, C. T., \& Hayesa, R. A., Social Media: Defining, Developing, and Divining, Taylor Francis Online, 2015, http://www.tandfonline.com/doi/abs/10.1080/15456870.2015.972282

Daee, A., Qowat-haye Khariji Dar Afghanistan Bayad Nabashad (There Must be no Foreign Forces in Afghanistan), Payam-e Haq, https://www.youtube.com/watch?v=3RVb1or9cPM, Accessed on December 17, 2015

Diamond, L., 'Liberation of Technology', Journal of Democracy, 2010, Volume 21, Issue 3, Pages 69-83

Earl, J., 'Studying Online Activism: The Effects of Sampling Design on Findings', Mobilization, 2013, http://www.mobilization.sdsu.edu/articleabstracts/184Earl.html

Farrell, H., 'The Consequences of the Internet for Politics', Annual Reviews, 2012, http://www.annualreviews.org/doi/full/10.1146/annurev-polisci-030810-110815

Fitri, K.B, 8,000 Facebook Accounts Created to Divide Afghans, Pajhwok Afghan News, October 6, 2015, http://www.pajhwok.com/en/2015/10/06/'8000-facebook-accounts-created-divide-afghans'

Gertz, B., Inside the Ring: Taliban Infiltrate Social Media, The Washington times, August 22, 2012 http://www.washingtontimes.com/news/2012/aug/22/inside-the-ring-taliban-inflate-social-media/?page=all 
Gwakh, B. A., The Taliban's Internet Strategy, Radio Free Europe Radio Liberty, September 9, 2011, http://www.rferl.org/content/the_talibans_internet_strategy/24323901.html

Hadef, Tohfa-e Degar-e Esteamar: Se Million Nafar Motad Ba Mawad-e Mokhader-and (Another Gift from Colonialism: Three Millions of People are Drug Addicts), Hizbut-Tahrir, May 19, 2015, http://ht-

afghanistan.com/article.php?lang=dari\&parent $=42 \&$ category $=5 \&$ aid $=4000$

Herrmann, J., How Social Media is Empowering Young Afghan Women: The Facebook Effect, The Independent, February 10, 2015, http://www.independent.co.uk/life-style/gadgets-and-tech/features/how-social-media-isempowering-young-afghan-women-the-facebook-effect-10375022.html

Hussainkhail, F., 60,000 Afghan Police are Illiterate, Tolonews, http://www.tolonews.com/en/afghanistan/1918160000-afghan-police-are-illiterate, Afghanistan, April 22, 2015

Ingram, H. J., Three Traits of the Islamic State's Information Warfare, RUSI, December 2014, https://www.rusi.org/publications/journal/ref:A54AAAB6F80360/\#.VhznlOyqpHw

Irfani, M., Aakheruzaman-e Farhang (Apocalypse of the Culture), Padidarha, http://padidarha.blogspot.com.es/2015/01/blog-post_97.html, Accessed on July 20, 2014

Kargar, Z., Why Was a Young Woman Killed by a Mob in the Streets of Kabul? Prospect Magazine, August 4, 2015, http://www.prospectmagazine.co.uk/world/why-was-a-young-woman-killed-by-a-mob-in-the-streets-of-kabul-

farkhunda-afghanistan

Kundnani, A., 'Radicalization: The Journey of a Concept', Race \& Class, 2012, http://rac.sagepub.com/content/54/2/3.short?rss=1\&ssource=mfr

Maruf, A. f, Jabh-e Jang-e Tablighati-e Taliban (Taliban's Propaganda War Front), BBC Persian Website, October 2, 2015, http://www.bbc.com/persian/afghanistan/2015/10/151002_taliban_propaganda_war_asif_maroof

Mazzetti, M., \& Gordon, M. R., ISIS is Winning the Social Media War, U.S. Concludes, The New York Times, June 12,2015, http://www.nytimes.com/2015/06/13/world/middleeast/isis-is-winning-message-war-usconcludes.html?_r=0

McCauley, C., \& Moskalenko, S., 'Mechanisms of Political Radicalization: Pathways towards Terrorism', Taylor Francis Online, 2008, http://www.tandfonline.com/doi/abs/10.1080/09546550802073367

Mehdi, S. Z., 'Refused Money to Buy Drugs, Husband Chops off Wife's Nose, Lips', Afghan Zariza, December 18, 2013, http://www.afghanzariza.com/2013/12/18/refused-money-to-buy-drugs-husband-chops-off-wifes-nose-lips,

Milan, S., 'Social Movements and Their Technologies Wiring Social Change', Palgrave Macmillan, London, November 2013, http://www.palgrave.com/page/detail/social-movements-and-their-technologies-stefaniamilan/?K=9780230309180

Ministry of Telecommunication and Information Technology (MCIT), Telecom Sector's Recent Achievements, Official Website of the MCIT, http://mcit.gov.af/en/page/4876/6005, Accessed on October 27, 2015

Mustanir, S., The Peace Process in Afghanistan is Political Suicide, The Khilafah, Afghanistan, March 9, 2015, http://www.khilafah.com/the-peace-process-in-afghanistan-is-political-suicide 
Mutawakil, A .h, Nawroz Wa Mullahai Shekamparast (Nawroz and Glutton Mullahs), Rashed Muslim, Mar 16, 2015, https://www.youtube.com/watch?v=iOyl5FGJKaA

Mutawakil, A., Hokme Amaliate Entehari, Esteshhadi, Fedaee? (Sentence for Suicide and Martyrdom Operation?), Khorasan Taghot Shekan, https://www.youtube.com/watch?v=sT6xNrHpq-4, Accessed on September 16, 2015

Khaharam! Mowazib Bash, Bazar Kamingah-e Gorg Hast (My Sister! Watch Out, Bazar is the Den of Wolves), Eslah Online, April 7, 2013, http://www.eslahonline.net/?p=42317

Neda, F., Mokhalefan Ba Ejad-e Safahat-e Jaali dar Facebook Mian-e Afghanha Tafriqa Andazi Mikunand (The Opposition uses Fake Facebook Pages to Create Divisions among Afghans), Radio Azadi, http://da.azadiradio.org/content/article/27292802.html, Accessed on October 7, 2015

Neumann, P. R., The Trouble with Radicalization, Chatham house, July 2013, https://www.chathamhouse.org/publications/ia/archive/view/193091

Noor Ebad, A., Hadisa-e Shahadat-e Khahar Farkhonda Zeer-e Zarabin-e Islam Wa Moqif-e Ulama dar Qebal-e Aan (The Martyrdom of Sister Farkhonda Under the Lens of Islam and the Position of Ulama Toward It), Paymanfilm Co, https, www.youtube.com/watch?v=Jtkv"ykpTknA, Accessed on March 27, 2015

Osman, B., The Fall of Kunduz: What Does This Tell Us About the Strength of Post-Omar Taliban?, Afghanistan Analysts Network, 30 September 2015, URL: https://www.afghanistan-analysts.org/the-fall-of-kunduz-what-does-ittell-us-about-the-strength-of-the-post-omar-taleban/

Porta, D. D., 'Processes of Radicalization and De-Radicalization', International Journal of Conflict and Violence, 2012, http://ijcv.uni-bielefeld.de/index.php/ijcv/article/view/266

Raghavan, S., \& Sharif, M., Afghan Flock to Kabul Taxi, a Satirical Facebook Page that Spares No One, Washington Post, July 11, 2015, https://www.washingtonpost.com/world/asia_pacific/afghans-flock-to-kabul-taxi-a-satiricalfacebook-page-that-spares-no-one/2015/07/11/64d17208-2737-11e5-b621-b55e495e9b78_story.html

Sarwari, B., Anatomy of an Afghan 'Turncoat' Killer, BBC, October 21, 2011, http://www.bbc.com/news/magazine14713523, Accessed on July 21, 2015

Shokoh, R., Bargozari-e Tazahorat Dar Mokhalifat Wa Hemayat Az Sima Joyandah Wali-e Ghor, (Protest against and in favor of Seema Joyenda, Governor of Ghor), Ufuq News Agency, October 18, 2015 http://www.ufuqnews.com/archives/21181

Social Media in Afghanistan: Measuring the Usage \& Perceptions of the Afghan Population, GIZ, Kabul, 2014, http://ez-afghanistan.de/fileadmin/content/news/Social_Media_251114.pdf

The Puppets and Their Masters are Playing with our Blood, The Khilafah, June 9, 2015, http://www.khilafah.com/thepuppet-rulers-and-the-crusader-invaders-are-equally-playing-with-our-blood/ Afghanistan

Wafayi, M., Afghans Boycott Pakistani Goods Over Taliban Claims, The Observers, August 20, 2015, http://observers.france24.com/en/20150820-taliban-attacks-afghanistan-boycott-pakistan-goods

We Strongly Condemn the Airstrike of the Colonialist Invaders and the Statement of Abdullah, Hizbut-Tahrir, June 30, 2015, http://ht-afghanistan.com/article.php?lang=english\&parent=43\&category=13\&aid=4315 
Ozwiat-e Daiemi Shanghai, Baraye Afghanistan Chera Mohim Ast? (Why Shanghai Membership is Important for Afghanistan?), Eslah Online, Afghanistan, July 13, 2015, http://www.eslahonline.net/?p=59573

Chera Shenidan-e Taranahaye Taliban Dar Mian-e Jawanan-e Afghan Bishtar Shoda Ast? (Why Taliban Songs Got More Popular Among Youth?), Azadi Radio, July 10, 2011, http://da.azadiradio.org/content/article/24261145.html

Women Under the Uthmani Khilafah: Challenging the Myths Women and Their Economic Rights, The Khilafah, March 8, 2015, http://www.khilafah.com/women-under-the-uthmani-khilafah-challenging-the-myths-women-andtheir-economic-rights-part-2/

Zaman, R., \& Mohammadi, A. A., Trends in Student Radicalization across University Campuses in Afghanistan, Afghan Institute for Strategic Studies, Kabul, October 2014, http://www.aiss.af/wpcontent/uploads/2015/09/English-version-Trends-in-Radicalization-across-Unregistered-Madrassas-inAfghanistan.pdf 


\section{ANNEXES}

\section{Annex 1: Sample Questionnaire}

1. How long have you been using social media?

2. What are some of the most popular social media platforms among your friends?

3. What are some of the ways in which you use social media?
a. Entertainment
b. Staying in touch with family members and friends
c. Following news and current affairs
d. Exchange of views on social and political affairs
e. Social and political mobilization, for example, street demonstrations
f. Others (please specify....................)

4. To what extent people you know in your area rely on social media to follow news and form opinions?

5. In your social media network, are you exposed to radical and violent messages and narratives? If yes, what are the central problems/issues around which those narratives and ideas are articulated?

6. Are those narratives and ideas intended for specific audiences, like youth, or any other particular groups or communities?

7. Are the radical narratives and ideas framed against some specific social and political groups?

8. To what extent those narratives and ideas call for violent strategies and tactics?

9. What are some of the ways you or people you know respond to the violent and radical messages and ideas that are being spread through social media? Please choose and elaborate on one of the following responses.
a. Ignore and do nothing about them
b. Debate and discuss their content and consequences with friends and family members
c. Actively oppose their diffusion and spread counter-radicalization ideas
d. Others (please specify

10. What are some of the ways in which social media is used to facilitate social mobilization in your area? Please choose and elaborate on one of the following responses.

a. Announcing planned public events and informing potential participants

b. Planning and coordinating the preparations for social events

c. Disseminating the news and messages of the events to the broader public

d. Others (please specify.....................) 
11. What are some of the ways in which social media is used by radical and violent groups? Please choose and elaborate on one of the following responses.

a. Recruitment and training of new members

b. Spreading and communicating narratives and ideas that call for violent actions

c. Coordinating and organizing violent activities

d. Others (please specify......................)

12. What are some of the main counter-radicalization narratives/ideas that are being circulated through your social media network?

13. What are some of the examples of civil society groups and individual activists' responses to radical narratives?

14. What are (if any) the existing official policies for countering or limiting the impact of radicalization through social media? 


\section{About the AISS}

The Afghan Institute for Strategic Studies (AISS) was established in October 2012 in Kabul. It aims to create an intellectual space for addressing strategic issues pertaining to Afghanistan in wider regional and international contexts. Promoting dialogue between and among different stakeholders is an end as well an integral means in attaining AISS' objectives. All activities and programs are based on the principles of professionalism, independence, internationalism and progressive values.

AISS is an independent research body, officially registered with the Afghan Ministry of Economy as a not-for-profit research institute dedicated to providing qualitative, non-partisan and policy-oriented research; publication, professional training and policy advocacy with a distinct focus on Afghanistan. Empowering and investing in Afghan youth constitutes the crosscutting priority of the AISS.

\section{Board of Advisors}

- Ambassador Kai Eide, former Special Representative to the UN Secretary General;

- Professor Radha Kumar, Director General, Delhi Policy Group (DPG);

- Mr. Nader Nadery, Director of Afghanistan Research and Evaluation Unit (AREU) and Head of the Free and Fair Election Foundation of Afghanistan (FEFA);

- Dr. Barnett Rubin, Director and Senior Fellow, Center on International Cooperation, and Professor of Political Science at New York University;

- Dr. Sima Samar, Chairwoman, Afghanistan Independent Human Rights Commission (AIHRC);

- Dr. Rangin Spanta, Former National Security, Government of Afghanistan;

- Professor Shahrbanou Tadjbakhsh, Chief Academic Advisor at the Afghan Institute for Strategic Studies (AISS), Director of the program on Human Security at the Master of Public Affairs (MPA), Institute of Political Studies, Sciences Po, Paris and Associate Researcher, Peace Research Institute Oslo (PRIO);

- Dr. David Samuel Sedney, Former Deputy Assistant Secretary of Defense for Afghanistan, Pakistan and Central Asia in the Office of the Assistant Secretary of Defense for Asian and Pacific Security Affairs; and

- Professor Wang Jisi, Dean, School of International Studies and Director of the Center for International and Strategic Studies, Peking University. 


\section{About the Authors}

Niamatullah Ibrahimi is a Research Fellow at the Department of Peace Studies at the AISS. Mr. Ibrahimi is currently pursuing his PhD at the Coral Bell School of Asia Pacific Affairs of the Australian National University. He has extensively conducted research and written on politics, history and current affairs in Afghanistan. He holds a graduate degree in Politics and International Relations from the London School of Economics and Political Science.

Musab Omer is a Researcher and Project Coordinator at the Department of Peace Studies at the AISS. His main areas of research are radicalization and political violence, as well as regional cooperation. Mr. Omer has done research on radicalization trends in unregistered madrassas and among university students across Afghanistan. He has also conducted research on the Heart of Asia Process, focusing on security and development in Afghanistan and its neighboring countries. Previously, he has also carried out an extensive research on orphans and women widowed due to conflict in Kashmir. He was also part of an Evaluation Study on Madrassa Modernization Scheme, implemented by the Government of India. He holds an MA in Conflict Analysis and Peace Building from Nelson Mandela Center for Peace and Conflict Resolution, Jamia Millia Islamia, New Delhi.

Mohammad Irfani is a Researcher at the Department of Peace Studies at the AISS. Mr. Irfani has earlier worked with BBC and Deutsche Welle and a number of local Afghan media organizations. He holds a BA in Sociology from the Ibn-e Sina University, Kabul. 
This Page Intentionally Left Blank

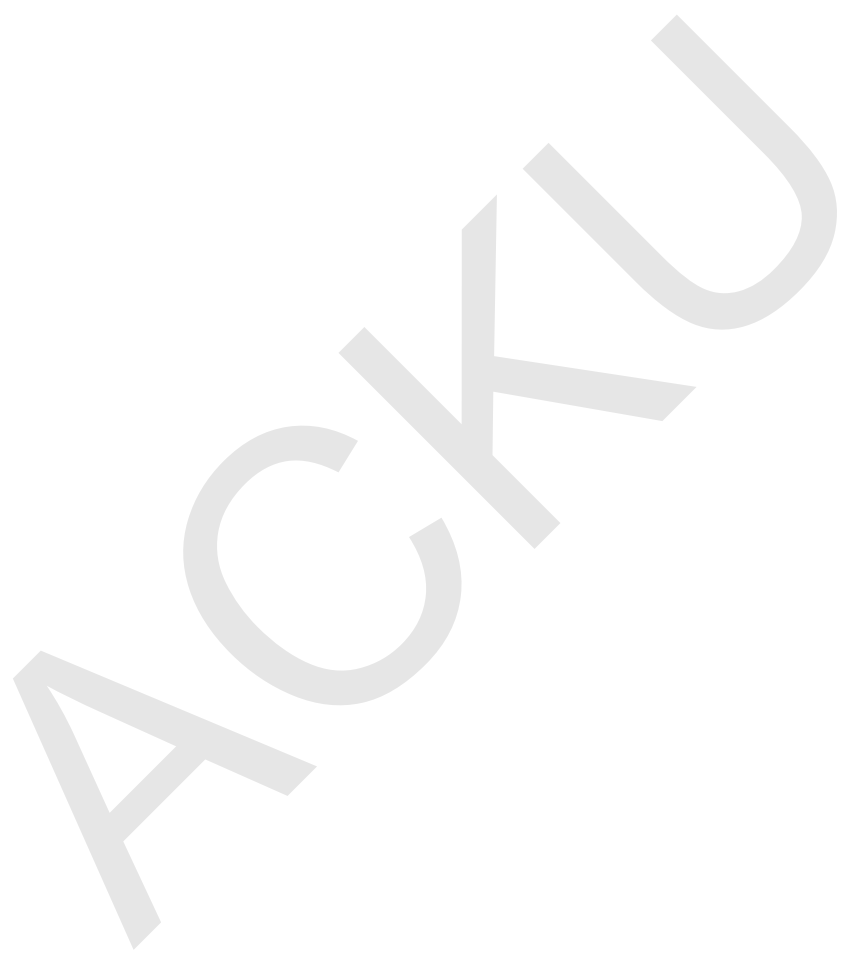




\section{CONTACT}

Afghan Institute for Strategic Studies (AISS)

Former Turquoise Mountain Fort I Post Box No: 5214 I Karte-Parwan I Kabul I Afghanistan

Musab Omer

Researcher and Project Coordinator, Department of Peace Studies

E: musab.omer@aiss.af

www.aiss.af I contact@aiss.af I Facebook: facebook.com/afghaninstituteforstrategicstudies

Twitter: @aissofficialpag I Linkedln: Afghan Institute for Strategic Studies

Commercial use of all publications by the AISS is not permitted without the written consent of the AISS.

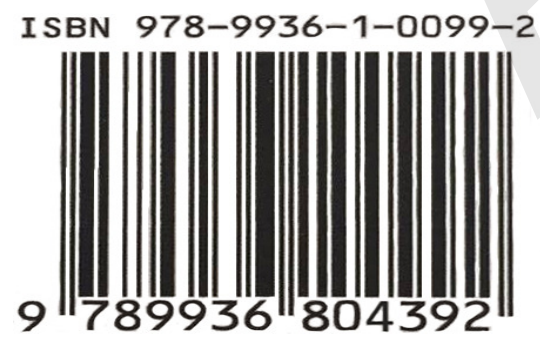

The analyses provided in this report are those of the research team and do not reflect the official position of Afghan Institute for Strategic Studies (AISS) or United States Institute of Peace (USIP). 